\title{
Eğitim Yönetimi Alanında Tez Yazmak: Mezunların Deneyimleri
}

\section{Writing Thesis in the Field of Educational Administration: Experiences of Graduates}

\begin{tabular}{|c|c|}
\hline \multicolumn{2}{|r|}{ Didem Koşar } \\
\hline Yazar Bilgileri & ÖZ \\
\hline $\begin{array}{l}\text { Didem Koşar } \\
\text { Doç. Dr., Hacettepe } \\
\text { Üniversitesi, Eğitim Bilimleri, } \\
\text { didemkosar@hacettepe.edu.tr }\end{array}$ & $\begin{array}{l}\text { Bu araştırmanın amacı eğitim yönetimi alanında yüksek lisansını tamamlayanların tez } \\
\text { sürecine ilişkin görüşlerinin incelenmesidir. Bu ana amaç doğrultusunda şu alt amaçlara } \\
\text { cevap aranmıştır: Eğitim Yönetimi alanında yüksek lisansını tamamlamış kişilerin (i) } \\
\text { lisansüstü eğitim yapma nedenlerine ilişkin görüşleri nelerdir? (ii) Tez sürecine iliş̧kin } \\
\text { görüşleri nelerdir? Konuyla ilgili olarak katılımcıların ayrıntılı ve derinlemesine görüşlerini } \\
\text { alabilmek amacı ile nitel araştırma yöntemi tercih edilmiştir. Araştırma olgu bilim } \\
\text { desenindedir. Çalışmada amaçlı örneklem yöntemlerinden maksimum çeşitlilik ve ölçüt } \\
\text { örneklem yöntemi kullanılmıştır. Araştırmanın çalışma grubunu, Ankara'da Eğitim } \\
\text { Yönetimi Ana Bilim Dalında yüksek lisanslarını tamamlamış olan } 12 \text { mezun } \\
\text { oluşturmaktadır. Araştırma sonunda eğitim yönetimi alanında yüksek lisansını tamamlayan } \\
\text { katılımclların çoğunluğu lisansüstü eğitim yapma nedenlerinin mesleki ve kişisel gelişim } \\
\text { olduğunu ifade etmişler; yüksek lisansı tamamlamanın kendilerine akademik anlamda, } \\
\text { bireysel olarak ve yeni çevre kazanma bağlamında getirileri olduğu konusuna } \\
\text { değinmişlerdir. Araştırmada tez sürecinin en büyük zorluğunun iş yaşam dengesini } \\
\text { sağlamak olduğu ortaya konmuştur. Tez sürecinde hissedilenlere ilişkin olarak } \\
\text { katıllımcların olumlu hislerden çok olumsuz ve karmaşı hisleri vurguladıkları } \\
\text { belirlenmiştir. Araştırmada tez konusu seçiminin, danışmanla iletişimin, planlı bir çalışma } \\
\text { takvimi oluşturtulmasının önemine ilişşin öneriler sunulmuştur. }\end{array}$ \\
\hline
\end{tabular}

\section{Makale Bilgileri}

Anahtar Kelimeler

Tez

Tez Süreci

Eğitim Yönetimi

Lisansüstü

\section{Keywords}

Thesis

Thesis Process

Educational Administration

Graduate

\section{Makale Geçmişi}

Geliş: 07.10.2021

Düzeltme: 20.11.2021

Kabul: 23.11.2021

\begin{abstract}
The aim of this research is to examine the views of those that completed master's degree in the field of educational administration about thesis process. Answers were sought for the following sub-objectives; (i) What are the views of those who have completed their master's degree in the field of educational administration about the reasons for postgraduate education?, (ii) What are their opinions about the thesis process?. Qualitative research method and phenomenological design were used. Maximum variation and criterion sampling method were used in the study. The study group consists of 12 graduates that completed master's degree in the field of Educational Administration in Ankara. The majority of the participants stated that the reason for postgraduate education is for professional and personal development. The majority of the participants mentioned that the thesis process has benefits for them academically, individually and in terms of participating in a new environment. The majority of the participants agree that the biggest challenge of the thesis process is to provide work-life balance Regarding the feelings during the thesis process, it is very striking that the participants expressed their feelings as negative and complex rather than positive feelings.
\end{abstract}




\section{Giriş}

Lisansüstü eğitim belirli bir alanda derinlemesine çalışmalar yaparken farklı bilgi, beceri ve sentezleme becerisi gerektiren, sorun çözebilme, bilgi üretebilme, mesleki alanlarda uzmanlaşma için yüksek ihtisas gücünü yetiştirmek amaçlı bir programdır (Çakar, 1997; Karaman ve Bakırcı, 2010). Lisansüstü eğitimin işlevleri ile üniversitelerin işlevleri kısmen benzerlik göstermektedir. Bilim ve sanat üretmek ve yaymak, toplumsal sorunları doğru algılayarak sorunlara çözüm önerileri geliştirmek ve üst düzey insan gücünün yetiştirilmesine katkıda bulunmak şeklindeki bu işlevler doğrultusunda, lisansüstü eğitimin önemi artmaktadır (Arıcı, 1997). Lisansüstü eğitimin ülke kalkınmasında ve ülkenin gereksinim duyduğu nitelikli insan gücünün oluşmasında önemli rolü bulunmaktadır (Sevinç, 2001). Karakütük (1989) lisansüstü eğitimin yaygınlaşmasının bazı sebeplerle kaçınılmaz olduğunu ifade etmektedir. Bu nedenlerin başında ülke kalkınması için gerekli insan gücünün yetiştirilmesi bulunmaktadır; diğer nedenler ise, kişisel ve mesleki gelişim ihtiyacı, lisans düzeyinde verilen eğitimin yeterli olmayışı ve maddi kazanç sağlamadır. Lisansüstü eğitim Türkiye'de, 1960'lı yılların sonlarına kadar sadece doktora eğitimi halinde 3-4 yıllık bir süreçte hocaasistan etkileşimi şeklinde yürütülmüştür. Sonrasında yüksek lisans ve doktora şeklinde iki kademeye bölünmüştür. $\mathrm{Bu}$ kademelerde uygulanacak kurallar günümüze kadar değişimlere uğrayan yönetmelikler çerçevesinde devam etmektedir (Çakar, 1997).

Yükseköğretim Sistemi, 2547 sayılı kanuna göre hazırlanmış olan Lisansüstü Eğitim ve Öğretim Yönetmeliği bağlamında lisansüstü eğitim ve öğretim programları, yükseköğretim kurumlarında yürütülen yüksek lisans, doktora ve sanatta yeterlik programlarından oluşmaktadır. Tezli yüksek lisans programının amacı, öğrencilerin bilimsel araştırma yöntemlerini kullanarak bilgiye erişme, bilgiyi derleme, yorumlama ve değerlendirme yeteneğini kazanmasını sağlamak iken tezsiz yüksek lisans programının amacı, öğrencilerin mesleki konularda bilgi kazanmasını sağlayarak mevcut bilginin uygulamada nasıl kullanılacağını öğrenmelerine yardımcı olmaktır (Yükseköğretim Kurulu [YÖK], 2016). Yüksek lisans programından mezun kişiler "Uzman" sıfatı kazanmaktadırlar (Arı, Pehlivanlar ve Çömek, 2005). Doktora programlarının amacı ise öğrenciye bağımsız araştırma yapma, bilimsel problemleri, verileri geniş ve derin bir bakış açısı ile irdeleyerek yorum yapma, analiz etme ve sentezlere ulaşmak için gerekli becerileri kazandırmaktır (YÖK, 2016). Doktora, lisansüstü eğitimin son basamağıdır. Ders, yeterlik ve tez aşaması bölümlerinden oluşan bu eğitimi başarıyla tamamlayanlara "Doktor" unvanı verilmektedir (Arı vd., 2005). Türkiye Yükseköğretim Yeterlilikler Çerçevesi (TYYÇ) 7. Düzey (Yüksek Lisans Eğitimi) Yeterlilikleri ve 8. Düzey (Doktora Eğitimi) Yeterlilikleri lisansüstü eğitimde öğrencilere kazandırılmak istenmektedir. Lisansüstü eğitim yeterlikleri; bilgi (kuramsal, uygulamalı), beceriler (kavramsal/bilişsel, uygulamalı) ve yetkinlikler (bağımsız çalışabilme ve sorumluluk alabilme yetkinliği, öğrenme yetkinliği, iletişim ve sosyal 
yetkinlik, alana özgü yetkinlik) olarak tanımlanmakta ve öğrencilere bu yeterliklerin kazandırılması hedeflenmektedir (YÖK, 2010).

Lisansüstü çalışma yapmanın anlamı programın öngörülen süresi içerisinde kişinin derinlemesine araştırmalar yaparak yeteneklerini geliştirmesi ve konuya ilişkin ayrıntılı rapor hazırlama becerisini ilerletmektir. Öğrenci ders dönemini tamamladıktan sonra geçtiği tez aşamasının sonunda tezini sunmalıdır (Bakioğlu ve Gürdal, 2001). Tez, öne sürülen fikir ve önermeleri içeren dokümanlardır ve belirli bir alanda yapılacak araştırmaya geniş bir bakış açısı kazandırır. Çalışma boyunca edinilen bilgiler ve varılan sonuçlar ile hipotez/hipotezler kanıtlanmaya çalışılır. Ancak tez konusu seçiminden konuyla ilişkili çalışmalar yapılma sürecine kadar pek çok farklı sorunlarla karşılaşılabilir. Çalışılacak tez konusu için derinlemesine ve yeterli okumaların yapılmaması veya ilgili konunun daha önce çalışılıp çalışılmadığı araştırılmadan konu seçiminin yapılması nedeniyle özgün çalışmaların ortaya çıkması zorlaşmaktadır. Yapılacak çalışmaların alana veya alanla ilgili olan unsurlara örneğin eğitim yönetimi alanında yöneticilere, öğretmenlere, öğrencilere, velilere, politika yapıcılara veya diğer araştırmacılara katkı sağlar nitelikte olması önemlidir. Kısaca bir tez, çalışmayı yapan kişiye akademik bir unvan kazandırmanın yanı sıra ilgili çevrelere de yarar sağlamalıdır (Oruç ve Ulusoy, 2008). Nitekim Karaman ve Bakırcı (2010) da lisansüstü eğitimin bir işlevinin toplumsal sorunları tespit edip bunlara çözüm önerileri geliştirmek olduğunu ifade etmekte ve bu yüzden yüksek lisansta yapılan çalışmaların ülke sorunlarını akademik ve kuramsal açıdan irdeleyen çalışmalar olmasını önermektedirler. Tez yazmak için gereken temel becerilerin öğrencide bulunması gerekir. Nasıl okunacağını, yazılacağını, literatürün nasıl analiz, sentez yapılacağını, nasıl ikna edici tarzda tartışma yazılacağını bilmeleri gerekmektedir. Teze başlarken bu beceriler bireyde yok ise, tezin bireye bu becerileri edinmeyi öğretmesi gerekmektedir. Tez bir öğrenme görevidir ve öğrencilere en yüksek entelektüel becerileri öğretmektedir. Plandan yoksun, iyi disipline edilmemiş, yeteri kadar dikkatle üzerinde çalışılmamış, iyi danışmanlık yapılmayan bir tez zamanında tamamlanamamaktadır. Tez sırasında gerçekleşmesi gereken ilerlemeler belirgin hale getirilmediğinden hem öğrenci hem de danışman için tezin değerlendirilmesi güçleşmektedir (Bakioğlu ve Gürdal, 2001).

Eğitim yönetimi alanı son yıllarda dünyada ve Türkiye'de kuram ve uygulama açısından önem kazanmıştır (Örücü ve Şimşek, 2011). Eğitim yönetimi alanında yeni bilgilerin üretilmesi, entelektüel sermayeyi etkili şekilde yönetebilen bir eğitim anlayışı ihtiyacını doğurmuştur. Özellikle, tezli ve tezsiz yüksek lisans ve doktora programlarının kuram ve uygulama bağının kurulması açısından bir köprü niteliği taşıdığı söylenebilir (Aküzüm, 2016). Eğitim yönetimi programlarının Türkiye'de de nispeten uzun sayılacak bir geçmişi bulunmaktadır. Balcı (2008) Türkiye'de eğitim yönetiminin bilimleşme sürecinin Ankara Üniversitesi Eğitim Fakültesinde açılan Eğitim İdareciliği ve 
Planlaması Bölümü ile başladığını belirtmektedir. Öğretmen ve eğitim yöneticisi yetiştirmek üzere kurulan Ankara Üniversitesi Eğitim Fakültesinde açlan Eğitim İdareciliği ve Planlaması Bölümünde (1964) eğitim programlarının ve kurumlarının işleyişine yönelik dersler okutulmuştur. Bu dersler arasında eğitim planlaması, eğitim ekonomisi, insan kaynakları, denetim ve teftiş gibi temel yönetim bilimi dersleri ile psikoloji, sosyoloji ve sosyal psikoloji gibi dersler de bulunmaktaydı. Ankara Üniversitesinin ardından Hacettepe Üniversitesi bünyesinde kurulan bölümde (1966) Eğitim Yönetimi alanında uzmanlık ve doktora programları açılmıştır. Bu programların amacı sadece eğitim yöneticisi yetiştirmek değil aynı zamanda kurumların ihtiyaç duyduğu eğitim uzmanlarını da yetiştirmektedir. 1997'de YÖK'ün Eğitim Fakültelerini tekrar yapılandırmasıyla Eğitim Yönetimi alanı bölümleri kapatılarak "anabilim dalı" düzeyine indirgenmiştir (Balc1, 2008). 2007 yılında Eğitim Yönetimi ve Politikası adıyla alan tekrar bölüme dönüştürülse de daha sonra tekrar anabilim dalına dönüştürülmüş ve YÖK kararı ile 2016 yılında tüm üniversitelerdeki anabilim dallarının adı Eğitim Yönetimi şeklinde değiştirilmiştir. Eğitim Yönetimi alanında lisansüstü eğitim, tezsiz ve tezli yüksek lisans programları ve doktora programlarıla yürütülmektedir. Tezsiz ve tezli yüksek lisans programindan "uzman" derecesi ile mezun olanlar, istedikleri takdirde doktora eğitimlerine devam ederek “Doktor (Ph.D.)" unvanını almaktadırlar.

Alanyazın incelendiğinde son yıllarda lisansüstü eğitim ile ilgili yapılan çalışmaların sayısında artış olduğu gözlemlenmekte; özellikle tez yazım sürecine odaklanan çalışmalara da yer verildiği görülmektedir. Bu bağlamda Kan ve Gedik'in (2016) Türkçe eğitimi alanında yüksek lisans tezi tamamlayanların tez sürecine ilişkin görüşlerini değerlendirdikleri çalışmada katılımcılar teze başlarken tez yazmak için gerekli olan akademik yazma becerisinde yeterli hissetmediklerini, tezden sonra akademik yazmaya ilişkin gelişme yaşadıklarını, bilimsel dili öğrendiklerini, literatür tarama ve ulaşmada yeterli hissettiklerini, yabancı dilde yazılmış makalelerden yeterince yararlanamadıklarını, tezin özetini ve bölümlerini yazmada çeşitli zorluklar yaşadıklarını ifade etmişlerdir. Yılmaz, Doğanalp ve Varol-Durmaz (2016) araştırmalarında lisansüstü öğrencilerin, içsel, dışsal ve süreçsel nedenlerden dolayı kaytarma davranışı sergiledikleri bunun sebepleri arasında ise motivasyon eksikliği, plansızlık, danışman hoca ile iletişimsizlik, intihal yapma korkusu, literatür yazma sürecine dair sıkıntılar, ilk kaynağa ulaşamama, zamanı iyi yönetememe, arkadaş çevresi, tezin öneminin kavranamaması ve ideal çalışma ortamının sağlanamamasının yer aldığı sonucuna ulaşılmıştır. Karadağ ve Ay'ın (2007) çalışmalarında da kaynaklara ulaşılmaması, istenilen konunun çalışılmaması, danışmanın yeterli dönüt verememesi, danışman ile uzmanlık alanının farklı olması, özgün bir konu bulmanın zorluğunu araştırma konusunun belirlenmesini zorlaştıran nedenler olarak ortaya konmuştur (aktaran Bahçeci ve Uşengül, 2018). Bahçeci ve Uşengül (2018) de yaptıkları araştırmada öğrencilerin tez konusu belirleme konusunda sıkıntı yaşadıkları sonucunu ortaya koymuşlardır. 
Bakioğlu ve Gürdal (2001) ise araştırmalarında öğrencilerin tez konularını kendilerinin belirlediklerini, ancak bazılarınınkinin danışman tarafından belirlendiğini, danışmanları ile sıkıntı yaşamaktan çekindiklerini, kütüphaneyi yeterli bulmadıklarını ve yabancı literatür konusunda sıkıntı yaşadıklarını belirtmişlerdir. Alanyazında özellikle eğitim yönetimi alanında lisansüstü eğitim gören öğrencilerin tez sürecine ilişkin nitel veri toplama teknikleri kullanılarak yapılan çalışmalar sınırlıdır. Buradan hareketle eğitim yönetimi alanındaki öğrencilerin tez süreci deneyimlerini, yaşadıkları zorlukları, kazanımlarını, önerilerini ortaya koymak önem teşkil etmektedir. Bu amaçla; eğitim yönetimi alanında yüksek lisans yapmış olanların tez sürecine ilişkin deneyimlerini betimleme bağlı oldukları enstitülere, danışmanlara, sürece yeni başlayan öğrencilere öneriler ve fikirler sunması açısından araştırma önemli görülmektedir.

\section{Araștırmanın Amacı}

$\mathrm{Bu}$ araştırmanın amacı eğitim yönetimi alanında yüksek lisansını tamamlayanların tez sürecine ilişkin görüşlerinin incelenmesidir. $\mathrm{Bu}$ ana amaç doğrultusunda şu alt amaçlara cevap aranmıştır; Eğitim Yönetimi alanında yüksek lisansını tamamlamış mezunların (i) lisansüstü eğitim yapma nedenlerine ilişkin görüşleri nelerdir?, (ii) tez sürecine ilişkin görüşleri nelerdir?

\section{Yöntem}

\section{Araştırmanın Deseni}

$\mathrm{Bu}$ araştırmada eğitim yönetimi alanı mezunlarının tez sürecine ilişkin görüşleri incelenmiştir. Konuyla ilgili olarak katılımcıların ayrıntılı ve derinlemesine görüşlerini alabilmek amacı ile nitel araştırma yöntemi tercih edilmiştir. Araştırma olgu bilim desenindedir. Olgu bilim deseninin kullanıldığı araştırmalarda veri kaynakları araştırmanın odaklandığı olguyu yaşayan veya bu olguyu yansıtabilecek birey veya gruplardır; amaç, bireyin bir olguya ilişkin yaşantılarını, algılarını ve buna yüklediği anlamları ortaya çıkartmaktır. Olgu bilim araştırmalarında sıklıkla kullanılan veri toplama araçlarından biri görüşmedir (Yıldırım ve Şimşek, 2016). Bu doğrultuda bu araştırmada derinlemesine incelenen olgu eğitim yönetimi alanında yüksek lisanslarını tamamlamış olan mezunların tez sürecine ilişkin yaşantılarıdır ve veri toplama aracı olarak görüşme kullanılmıştır.

\section{Çalışma Grubu}

Araştırmanın çalışma grubunu, Ankara'da bir devlet üniversitesi Eğitim Fakültesi Eğitim Bilimleri Bölümü Eğitim Yönetimi Ana Bilim Dalında yüksek lisanslarını tamamlamış olan 12 mezun oluşturmaktadır. Çalışmada amaçlı örneklem yöntemlerinden maksimum çeşitlilik ve ölçüt örneklem yöntemi kullanılmıştır. Maksimum çeşitlilik örnekleme yöntemi kullanılmasının amacı çalışma grubunun çeşitliliğinin sağlamadır. Çalışma grubuna seçilecek kişilerin belirlenmesinde cinsiyet, yaş, meslek gibi değişkenler çeşitlilik kaynağı olarak alınmış böylelikle çalışma grubunun çeşitliliği sağlanmıştır. Ölçüt örneklem problemle ilgili olarak belirlenen niteliklere sahip kişiler, olaylar, 
nesneler ya da durumlardan oluşturulmasıdır (Büyüköztürk, Kılıç-Çakmak, Akgün, Karadeniz ve Demirel, 2015). Araştırmada belirlenen ölçüt ise kişilerin yüksek lisans tez dönemlerini tamamlamış olmalarıdır. Araştırmanın çalışma grubunu oluşturan katılımcıların sekizi kadın dördü erkektir; yaşları 28 ile 39 arasında değişmektedir. Katılımcıların sekizi öğretmen, ikisi müdür ve ikisi memur olarak görev yapmaktırlar.

\section{Veri Toplama Araçları}

Araştırmada veri toplama aracı olarak araştırmacı tarafından geliştirilen yarı yapılandırılmış görüşme formu kullanılmıştır. Yarı yapılandırılmış görüşme formu oluşturulurken ilgili alanyazın ayrıntılı olarak taranmış ve lisansüstü eğitim sürecinde tez dönemine ilişkin yaşantıları ortaya çıkarabilecek sorular oluşturulmaya çalışılmıştır. Hazırlanmış olan taslak görüşme formu için uzman görüşüne başvurulmuştur. Uzman görüşleri doğrultusunda birbirine benzer soru ifadeleri, sorulardaki karmaşık ifadeler, araştırma amacına hizmet etmediği düşünülen sorular değiştirilerek görüşme formuna son şekli verilmiştir. Görüşme formu iki bölümden oluşmaktadır. Birinci bölümde katılımcıların yaş ve mesleklerinin yer aldığı demografik bilgiler bölümüdür. İkinci bölüm ise (i) Lisansüstü eğitime başlama nedenleriniz neler?, (ii) Tez yazma sürecinin size kazandırdıkları nelerdir?, (iii) Tez yazma sürecinde karşılaştığınız zorluklar nelerdir?, (iv) Tez sürecindeki hislerinizi nasıl tarif edersiniz?, (v) Tez sürecindeki öğrencilere önerileriniz neler? sorularının yer aldığı ikinci bölümdür.

\section{Verilerin Toplanması ve Analizi}

Araştırma verilerinin toplanabilmesi için Hacettepe Üniversitesi Senatosu Etik Komisyonunun 28.07.2020 tarih ve 35853172-600 sayılı izni alınmıştır. Görüşmeler eğitim yönetimi alanında tez sürecini tamamlamış mezunlar ile lisansüstü eğitimlerini tamamladıkları üniversitede belirlenen gün ve saatte yüz yüze gerçekleştirilmiştir. Görüşmeler 2020 yılı Temmuz ile Aralık ayları arasında tamamlanmıştır. Görüşmeler başlamadan önce katılımcılarla araştırmanın amacı hakkında kısa bir görüşme yapılmış ve uyulması gereken etik ilkeler bağlamında kendilerine kimliklerinin gizli kalacağı bu nedenle kimliklerini belli etmek durumunda olmadıkları bildirilmiştir. Katılımcılarla yapılan görüşmelerde olası veri kaybını önlemek amacı ile görüşme formunda yer alan soruların cevaplarının sadece araştırmacı tarafından dinleneceği belirtilerek katılımcıların izni istenmiş ve görüşmeler ses kayıt cihazı ile kayıt altına alınmıştır. Ses kayıt cihazının yanı sıra olası herhangi bir teknik arıza durumunda veri kaybı yaşamamak amacı ile not tutma tekniği de kullanılarak görüşmeler esnasında katılımcıların cevaplarının bir kısmı not alınmıştır. Yapılan görüşmeler yaklaşık 20 ile 45 dakika arasında sürmüştür. Kayıt altına alınan her bir görüşme araştırmacı tarafından bilgisayar ortamına aktarılmıştır. Görüşmeden elde edilen veriler katılımcıların gönüllü katılım formunda belirttikleri eposta adreslerine gönderilerek verilerin doğruluğu konusunda kendilerinden teyit alınmıştır. 
Verilerin analizinde içerik analizi kullanılmıştır. İçerik analizi insan davranışlarını üzerinde doğrudan olmayan yollarla çalışmaya imkân tanıyan ve sosyal bilimlerde sıklıkla kullanılan bir tekniktir. İçerik analizi birbirine benzeyen verilerin belirli kavramlar, kategoriler ve temalar çerçevesinde bir araya getirilmesi ve anlaşılabilir biçimde düzenlenerek yorumlamaya yardımcı olmasını sağlayan bir yöntemdir. Nitel araştırma verileri, verilerin kodlanması, temaların bulunması, kodların ve temaların düzenlenmesi ile bulguların tanımlanması olmak üzere dört aşamada analiz edilir (Yıldırım ve Şimşek, 2016). Araştırmada katılımcı görüşmeleri araştırmanın amacına, alt amaçlarına göre kodlanmıştır. Katılımcıların görüşlerinden elde edilen kodlar bir araya getirilmiş benzer yönler dikkate alınarak gruplandırılarak alt temalara ulaşılmıştır. Katılımcıların görüşlerini yansıtabilmek için kod ve alt temalara uygun özellikteki doğrudan alıntılara yer verilmiştir. Çalışma grubunda yer alan katılımcıların gizliliğini sağlamak için ise cinsiyetlerine uygun isim verilerek kodlanmışlardır.

\section{Geçerlik ve Güvenirlik}

Geçerlik ve güvenirlik, araştırma sonuçlarının inandırıcılığını sağlamak için kullanılan en önemli iki ölçüttür (Yıldırım ve Şimşek, 2006). Bu bağlamda eğitim yönetimi alanında tez yazmış mezunların deneyimlerine odaklanan bu araştırmada iç geçerlik, araştırmada kullanılan yarı yapılandırılmış görüşme formunun uzman incelemesi yapılması, ses kayıtlarının bilgisayarda Word formuna alındıktan sonra katılımcılara tekrar yönlendirerek katılımcı teyidi alınması, analizler sonucunda ortaya konan bulguların görüşmelerden elde edilen doğrudan alıntılarla verilmesi, veri toplama aracının ve bulguların ilgili alanyazın ile tutarlılığı ile sağlanmaya çalışılmıştır. Dış geçerlik, araştırma yöntem ve deseni ile ilgili bilgiler verilerek gerçekleştirilmeye çalışılmıştır. Araştırma sonuçlarının verilerle tutarlığına ilişkin tutarlık incelemesiyle iç güvenirlik, veri toplama sürecinin ve analizinin ayrıntılı betimlenmesi yoluyla da dış güvenirlik sağlanmaya çalışılmıştır.

\section{Bulgular}

\section{Lisansüstü Eğitim Yapma Nedenlerine İlişkin Bulgular}

Araştırmanın ilk alt problemi doğrultusunda katılımcılara lisansüstü eğitim yapma nedenlerinin neler olduğu sorusu yöneltilmiştir. Verilen cevaplar doğrultusunda lisansüstü eğitim yapma nedenlerinin üç alt temada toplandığı görülmüştür. Bu temalar etkileşim, gelişim ve katkı şeklindedir. Aşağıda Şekil 1'de belirlenen temalar görülmektedir. 


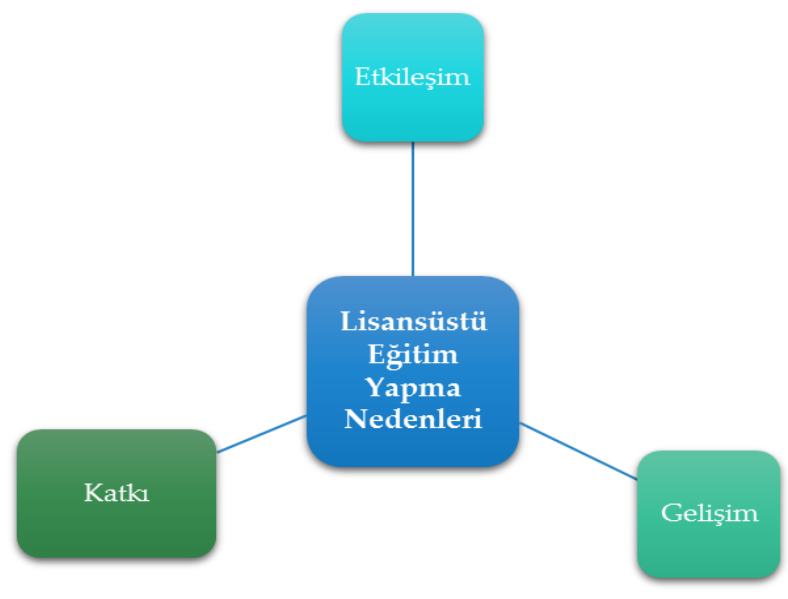

Şekil 1. Lisansüstü Eğitim Yapma Nedenleri

Etkileşim alt teması altında akademik çevre etkileşimi, akran etkileşimi kodları yer alırken gelişim alt teması altında mesleki gelişim, kariyerde ilerleme ve yaşam boyu öğrenme kodları belirlenmiştir. Son alt tema olan katkı altında ise hizmet puanı ve bilim kodları belirlenmiştir. Aşağıda Tablo 1'de birinci alt problem doğrultusunda ortaya konan alt tema, kod ve katılımcıların örnek ifadelerine yer verilmektedir.

Tablo 1. Lisansüstü Eğitim Yapma Nedenleri

\begin{tabular}{|c|c|c|}
\hline $\begin{array}{l}\text { Alt } \\
\text { Tema }\end{array}$ & Kodlar & Katılımcılarn Ífadeleri \\
\hline \multirow{4}{*}{ 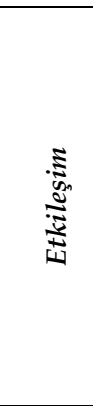 } & \multirow{2}{*}{$\begin{array}{l}\text { Akademik } \\
\text { Çevre }\end{array}$} & $\begin{array}{l}\text { Ayşe: Öğretmenliğimde bazen yetersiz hissettim, mesleki anlamda değil farklı çevreye ihtiyaç } \\
\text { duydum; kendimi geliştirmeme yardımcı olacak bir çevreye. }\end{array}$ \\
\hline & & $\begin{array}{l}\text { Neslihan: Kendimi kesinlikle bulunduğum ortamdaki kişilerle etkileşimden sıkıldığımı hissettiğim } \\
\text { noktada farklı, alanında uzman, sürekli gelişime önem veren bir akademik camiada hissetmek } \\
\text { istedim. }\end{array}$ \\
\hline & \multirow{2}{*}{ Akran } & $\begin{array}{l}\text { Osman: Öncelikle yapmış olduğum işten dolayı kendimi geliştirme isteğiydi daha sonra çevremdeki } \\
\text { çoğu insan ve iş arkadaşlarım yüksek lisans veya doktora öğrenimi yapıyordu bende lisansüstü } \\
\text { öğrenim yapmaya karar verdim. }\end{array}$ \\
\hline & & $\begin{array}{l}\text { Eren: Her üniversite mezunu olan öğrencinin düşündüğü gibi üniversiteden mezun olduktan sonra } \\
\text { yüksek lisans yapma düşüncem vardı. }\end{array}$ \\
\hline \multirow{6}{*}{ 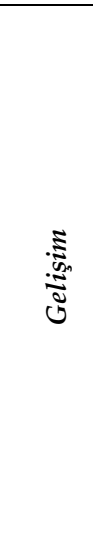 } & \multirow{6}{*}{$\begin{array}{l}\text { Mesleki ve } \\
\text { Kişisel }\end{array}$} & $\begin{array}{l}\text { Aydan: Mesleğimle ilgili daha profesyonel olmak, kendimi geliştirmek, akademik kariyer ve kariyer } \\
\text { grubu mesleklere geçmek, eğitim yönetimi alanında uzmanlaşma. }\end{array}$ \\
\hline & & $\begin{array}{l}\text { Gamze: Yapacağım işin teorik eğitimini alarak bilinçli bir şekilde işimi yapmak, kendimi } \\
\text { geliştirmek, yeni bilgilerle kendimi daha mutlu hissetmek. }\end{array}$ \\
\hline & & Ezgi: Lisansüstü eğitimle, bilgi birikimimi genişletmek, kişisel ve mesleki gelişimimi artırmak. \\
\hline & & $\begin{array}{l}\text { Şükran: Kendi alanımda bilgi birikim sahibi olmanın yanında kendimi geliştirmek öncelikli } \\
\text { nedenlerim içerisinde yer almaktadır. Kamu personeli olmam sebebiyle çalışmamı yaptığım alanda } \\
\text { öğrendiklerimle kamuda işimde uzmanlaşmak. }\end{array}$ \\
\hline & & $\begin{array}{l}\text { Leyla: Öğretmenlik lisans programında okurken eğitim bilimleri dersleri bölüm derslerinden daha } \\
\text { fazla ilgimi çekmişti. Bunda Anadolu öğretmen lisesi mezunu olmamın ve liseden beri eğitim } \\
\text { bilimleri dersleri almamın etkisi de vardı. Bu nedenle bu alanda kendimi geliştirmek istedim. }\end{array}$ \\
\hline & & $\begin{array}{l}\text { Ali: Öğretmenlik mesleği içinde kendimi yenileme ihtiyacı, zamanın getirdiği eğitim noktasındaki } \\
\text { yeni yaklaşımları takip edebilmek, eğitimde yeni yayınları ve akademik çalışmalardan uzak } \\
\text { kalmama isteği. }\end{array}$ \\
\hline
\end{tabular}


Sezer: Son 10 yıldır idareci olarak çalışıyorum. Bu alanda da ilerlemek mesleki hedeflerim arasında. $\mathrm{Bu}$ hedefimden dolayı tez konumu bile okul müdürleri üzerine yaptım. Bundan dolayı hem yönetim hem de eğitim alanında teorik bilgi anlamında yeni bir şeyler öğrenmek, yeniliklerden haberdar olmak, mesleki anlamda kendime katkısının olacağını düşündüğüm için lisansüstü eğitime başladım. Okulda yönetim anlamında her yıl hemen hemen aynı işlerin yapılmasından dolayı az bir bilgi ile veya üniversitede alınan bilgi ile meslek devam ettirilebiliyor. Oysaki eğitim öğretim süreci de sürekli değişen bir süreç. Çağ değişiyor, teknoloji değişiyor, insanlar değişiyor, eğitimden beklentiler değişiyor. Bu değişimlerden haberdar olmak ve bu değişimlere ayak uydurmak için de lisansüstü eğitime başladım.

Leyla: Eğitim sisteminin sürekli değişmesi ve programların güncellenmesi bende bu değişim sürecinin bir parçası olma isteği uyandırmıştı. Yöneldiğim alanda alacağım eğitimle iş dünyasında da farklı kapıların açılabileceğini ummuştum. Sadece akademi dünyasında yer almak değil milli eğitim bakanlı̆̆ının çeşitli birimlerinde uzmanlaşabilmeyi ve sisteme katkı sağlayabilmeyi beklemiştim. Yani aslında amacım sadece akademisyen olmak değildi. Öğretmenliğin dışında

Kariyer eğitim sisteminin içinde yer alabilmek için lisansüstü eğitime başlamıştım.

Meltem: İlgi duyduğum alanda daha fazla bilgi sahibi olmak, araştırma yapmak, alanında yetkin hocalardan ders almak ve uzmanlaşmak; çalıştığım kurumda farklı pozisyonlarda görev alabilmek; doktora eğitimine de devam ederek öğretim üyesi olabilme ihtimalini değerlendirmek.

Ali: Kariyer için bir basamak oluşu.

Osman: Diğer taraftan eğitimin bu kadar önemli olduğu bir zamanda daha iyi kariyer imkânlarına sahip olmak da lisansüstü eğitime başlamamın nedenlerinden biridir.

\begin{tabular}{ll}
\hline $\begin{array}{l}\text { Yaşamboyu } \\
\text { Öğrenme }\end{array}$ & Ali: Öğrenme yaşam boyu devam eden bir süreç. \\
\hline & $\begin{array}{l}\text { Sezer: Arkadaşlarımızın arasında yönetici atama sürecinde kullanılan Ek-1 formundaki yüksek } \\
\text { lisansa verilen +3 puan için başlayanlarda var. Bunlar daha çok uzaktan eğitim yoluyla lisansüstü } \\
\text { eğitim yapanlar. }\end{array}$ \\
\cline { 2 - 3 } & $\begin{array}{l}\text { Eren: Aradan yıllar geçtikten sonra Ankara'ya atamam yapılınca daha önce yaptığım okul } \\
\text { yöneticiliğini devam ettirmek için ve Milli Eğitim Bakanlığı Eğitim Kurumları Yönetici } \\
\text { Görevlendirme Yönetmeliğinde geçen yüksek lisans mezunu öğretmenlere verilecek ek puandan } \\
\text { faydalanabilmek için tezsiz yüksek lisansa başlayınca üniversite ortamını özlediğimi anladım. }\end{array}$ \\
\hline Bilim & Ezgi: Bilimsel hayata ürettiklerimle bir nebze de olsa katkı sağlayabilmek amactyla başladım.
\end{tabular}

Tablo 1'de görüldüğü üzere katılımcıların üçü akademik çevre etkileşimi, ikisi ise akran etkileşimi konularında görüş bildirmişledir. Mesleki ve kişisel gelişim kodunda dokuz katılımcı görüşlerini dile getirirken kariyerde ilerleme kodunda üç katılımcı, yaşam boyu öğrenme kodunda ise bir katılımcı görüşlerini ifade etmişlerdir. Son alt tema olan katkıda ise hizmet puanı kodunda iki, bilim kodunda ise bir katılımcı görüş bildirmişlerdir. En çok görüş bildirilen kod mesleki ve kişisel gelişim iken en az vurgulanan kodlar yaşam boyu öğrenme ve bilim olmuştur.

\section{Tez Sürecine İlişkin Bulgular}

Araştırmada ikinci alt problem doğrultusunda katılımcılara tez sürecine ilişkin görüşleri sorulmuştur. Verilen cevaplar doğrultusunda tez sürecinin kazandırdıkları, tez sürecinin zorlukları, tez sürecinde yaşanan hisler ve tez sürecindeki öğrencilere önerilere yönelik görüşler sunulmuştur. Bu bağlamda tez sürecine ilişkin olarak dört tema belirlenmiştir. Bunlar getiriler, zorluklar, hisler ve öneriler şeklindedir. Tez sürecinin getirileri temasında belirlenen alt temalar akademik katkı, bireysel katkı ve çevredir. Tez sürecinin zorlukları temasında belirlenen alt temalar danışman kaynaklı, konu kaynaklı, zaman kaynaklı, veri toplama süreci kaynaklı, analiz süreci kaynaklı, kişisel kaynaklıdır. Tez sürecindeki hisler temasında belirlenen kodlar olumlu, olumsuz ve karmaşıktır. Tez süreci önerilerine ilişkin olarak konu, danışman, zaman yönetimi, yazma ve destek alt temaları belirlenmiştir. 


\section{Tez Sürecinin Getirileri:}

Tablo 2'de tez sürecinin getirilerine ilişkin alt tema, kod ve katılımcıların örnek ifadelerine yer verilmektedir.

Tablo 2. Tez Sürecinin Getirileri

\begin{tabular}{|c|c|c|}
\hline $\begin{array}{c}\text { Alt } \\
\text { Temalar }\end{array}$ & Kodlar & Katılımcilarn Iffadeleri \\
\hline \multirow{9}{*}{  } & \multirow[t]{2}{*}{$\begin{array}{l}\text { Literatür } \\
\text { Tarama }\end{array}$} & $\begin{array}{l}\text { Leyla: Tez yazma sürecinde makale okuma alışkanlığı kazandım. Literatür taraması } \\
\text { konusunda ilerleme kaydettim. En azından akademik bir çalışma yapmak istediğimde } \\
\text { hangi kaynaklardan ne şekilde yararlanabileceğimi görmüş oldum. Ayrıca alanyazın } \\
\text { taramasında o kadar farklı kaynak görme şansım oldu ki karşılaştığım kaynaklarda ne } \\
\text { yapmamam gerektiğini de uygulamalı olarak görmüş oldum. Bu da bana aslında eleştirel } \\
\text { bakış açısı kazandırdı diyebilirim. }\end{array}$ \\
\hline & & $\begin{array}{l}\text { Osman: Tez yazma sürecinin bana kazandırdıkları kazanımlardan bazıları disiplinli } \\
\text { çalışma, bir konu hakkında araştırma nasıl yapılır kaynak ve literatür taraması nasıl yapılır } \\
\text { nelere dikkat edilir hususu bana kazandırdığı önemli değerlerdir. }\end{array}$ \\
\hline & Analiz & $\begin{array}{l}\text { Şükran: Bir araştırmanın nasıl yapıldığı nasıl yapılacağı ve nelerin önemli kıstas olduğu } \\
\text { farkındalığına sahip olmamı sağladı. }\end{array}$ \\
\hline & \multirow{2}{*}{$\begin{array}{l}\text { Bilimsel Yayın } \\
\text { Okuma } \\
\text { Alışkanlı̆̆ı }\end{array}$} & Ayşe: Nicelikle en büyük katkısı bana kaynak okuma fırsatı sağlamaması oldu. \\
\hline & & $\begin{array}{l}\text { Şükran: Ayrıca akademik çalışmaların yapıldığı araştırmaları okumayı öğrendim. } \\
\text { Akademik sözlüğün önemini bir kez daha anlamış oldum. }\end{array}$ \\
\hline & $\begin{array}{l}\text { Akademik } \\
\text { Yazma Becerisi }\end{array}$ & $\begin{array}{l}\text { Ezgi: Mesleğimle ilgili kuramsal bilgileri değerlendirmeme yardımcı oldu. Akademik yazma } \\
\text { becerilerimin geliştiğini fark ettim. Hâlihazırda okul/kurum bazlı proje yazarken tez yazma } \\
\text { sürecinde kazandıklarımın faydasını görmekteyim. }\end{array}$ \\
\hline & \multirow{2}{*}{ Sentezleme } & $\begin{array}{l}\text { Leyla: Çalıştı̆̆ım alanla ilgili her bilgi dikkatimi çekmeye başladı ve bu konudaki } \\
\text { gelişmeleri takip etmeye başladım. Yanlış yöntemlerle başlamaya çalıştığımı fark edip } \\
\text { kendi çalışma yöntemimi buldum. Şu an bir araştırma yürütmek istediğimde ya da bir } \\
\text { makale yazmak istediğimde en azından nasıl bir yol izleyeceğime biraz daha hâkim oldum. }\end{array}$ \\
\hline & & $\begin{array}{l}\text { Meltem: Bir konuda uzmanlaşmaya çalışırken karşınıza çok fazla kitap, makale, tez } \\
\text { çıabiliyor ve hepsini okuyarak özümsemek, tabi bir yandan bunların arasında } \\
\text { kaybolmamak gerekiyor. Tez yazma sürecinde en doğru ve yalın bilginin çalışmaya nasıl } \\
\text { aktarılacağını da öğrendim. }\end{array}$ \\
\hline & Farkındalık & $\begin{array}{l}\text { Sezer: Tez yazma süreci gerçekten zor, zaman isteyen, bol bol okuma ve araştırma isteyen } \\
\text { bir süreç. Bana en başta } 24 \text { saati planlama alışkanlığı kazandırdı. Tez yazma sürecinde uzun } \\
\text { zaman sonra kütüphane kullanma alışkanlığını ve makale okuma alışkanlığını tekrar } \\
\text { kazandım. Bunların dışında kaynak vererek bilgi paylaşmayı, parça parça bilgilerden bir } \\
\text { bütün oluşturarak bir tez meydana getirmeyi öğrendik. Bizler genellikle kulaktan dolma } \\
\text { bilgi ile çok fazla eğitim konusu ile ilgili meslektaşlarımızla tartışıoruz. Tez yazma } \\
\text { sürecimde belki de ilk öğrendiğim şey "Bu sözü kim söylemiş.", "Bu cümle kime ait ise } \\
\text { parantez içinde adı soyadı, kitap adı, sayfa numarası yazılacak." cümleleriydi. Bunları } \\
\text { cümlelerin altına yazarken eğitim öğretim alanında, yönetim alanında çalışma yapan } \\
\text { yurtiçi ve yurtdışından akademisyenler, yazarlar hakkında bilgi sahibi oldum. } \\
\text { Üniversitelerimizin Eğitim Yönetimi ve Denetimi bölümünde hangi hocalarımız olduğunu } \\
\text { ve hangi konular üzerine çalışma yaptıklarını öğrendim. }\end{array}$ \\
\hline \multirow{5}{*}{  } & Planlama & Aydan: Artık zamanımı daha iyi yönetebiliyorum. \\
\hline & Sabır & Ayşe: Bana en büyük kişisel katkısı kesinlikle sabırlı olmayı öğretmesi oldu. \\
\hline & \multirow[t]{2}{*}{ Bakış Açıları } & $\begin{array}{l}\text { Aydan: Verilen ödevleri yaparken dahi bilimsel bir veri nasıl ortaya çıkar bu süreci } \\
\text { öğrenmiş oluyoruz ve bu da hayata ve mesleğime bakış açımı, sorunlara yaklaşma } \\
\text { yöntemimi geliştiriyor. }\end{array}$ \\
\hline & & $\begin{array}{l}\text { Gamze: Akademik dünyanın farklı yönleri hakkında bilgiler edindim, araştırıp öğrenerek, } \\
\text { okuyarak gelişmeme, düşüncelerime farklılık kattı ufkumu, bakış açımı genişletti. }\end{array}$ \\
\hline & Gerçeklik Şoku & Ali: Saha ziyaretleri içinde gerçekle yüzleştim. \\
\hline \multirow[b]{2}{*}{ 文 } & Yeni Dostluklar & Ali: Sosyalleştim. \\
\hline & $\begin{array}{l}\text { Alan Hocalar } \\
\text { Etkileşimi }\end{array}$ & $\begin{array}{l}\text { Eren: Yeni bir çevrem oldu. Yeni dostluklar edindim. Çok değerli akademisyenlerle } \\
\text { tanışma imkânı buldum. Daha çok akademik ortamlarda bulunma şansı yakaladım. } \\
\text { Sempozyum ve kongrelere katılarak çalışmalarımızı farklı kişilere sözlü olarak anlatma } \\
\text { imkânı buldum. }\end{array}$ \\
\hline
\end{tabular}

Tablo 2'de görüldüğü üzere bireysel katkı alt temasında planlama, sabır ve gerçeklik şoku kodlarında birer katılımcı görüş bildirirken, bakış açıları kodunda iki katılımcı görüş bildirmişlerdir. 
Çevre kodunda bir katılımcı yeni dostluklar bir katılımcıda alandaki hocalarla etkileşim kodlarında düşüncelerini ifade etmişlerdir. Akademik katkı kodunda ise literatür tarama, bilimsel yayın okuma alışkanlığı, akademik yazma becerisi ve sentezleme kodlarında iki, analiz, farkındalık kodlarında ise birer katılımcı görüşlerini söylemişlerdir. Katılımcılar tarafından en çok vurgulanan kodlar arasında literatür tarama, bilimsel yayın okuma alışkanlığı, akademik yazma becerisi, sentezleme ve bakış açıları yer alırken en az vurgulananlar analiz, farkındalık, planlama, sabır, gerçeklik şoku, yeni dostluklar ve hocalarla etkileşim olmuştur.

\section{Tez Sürecinin Zorluklarn:}

Tablo 3'te tez sürecinin zorluklarına ilișkin alt tema, kod ve katılımciların örnek ifadelerine yer verilmektedir.

Tablo 3. Tez Sürecinin Zorlukları

\begin{tabular}{|c|c|c|}
\hline $\begin{array}{l}\text { Alt } \\
\text { Temalar }\end{array}$ & Kodlar & Katılımcılarm Ífadeleri \\
\hline \multirow{8}{*}{ 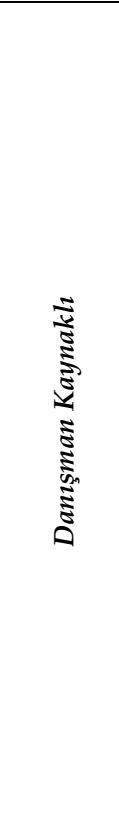 } & İletişim & $\begin{array}{l}\text { Osman: Yardım alabileceğiniz veya her konuda danışabileceğiniz bir danışmanın olması da } \\
\text { oldukça önemli. Ancak burada ifade edilmese bile bu zorlukların aşılmasındaki en önemli } \\
\text { etkenin danışman olduğu hususunu öğrenmiş oldum. }\end{array}$ \\
\hline & Baskı & $\begin{array}{l}\text { Hülya: Sürekli olarak bana örnek tezler yollayarak "bak bunlara benzer şekilde" ilerle } \\
\text { demesi, ama aynı zamanda diğer hocalarla iletişimim konusunda çok açık olmaması beni çok } \\
\text { zorladı. }\end{array}$ \\
\hline & \multirow[b]{2}{*}{ Dönüt } & $\begin{array}{l}\text { Aydan: Danışmanın yetersiz rehberliği. Gönderdiğim dosyalara cevap vermesinin çok ama } \\
\text { çok uzun sürmesi. }\end{array}$ \\
\hline & & $\begin{array}{l}\text { Şükran: Danışman-öğrenci ikili ilişkilerinin çok iyi olması gerekir tezin sağlıklı şekilde } \\
\text { ilerleme kaydedilebilmesi için feedback yapılması süresinin iyi olması gerekir bende ne } \\
\text { yazık ki en büyük problemlerden biri olmasından ötürü süreçte verim alma konusunda } \\
\text { sıkıntılarım olmuştu. }\end{array}$ \\
\hline & \multirow{4}{*}{ Tez Konusu } & $\begin{array}{l}\text { Gamze: Tez yazma süreci özellikle teze başlama çalışılmak istenen konuyla, bize dikte } \\
\text { edilmeye çalışılan konuları kabullenme aşamasında zorluklar yaşadım. }\end{array}$ \\
\hline & & $\begin{array}{l}\text { Leyla: Ben konu açısından çok zorlandım. Çalışmak istediğim konu daraltması zor olan } \\
\text { kapsamlı bir konuydu. Ayrıca uygulama içermeyen kuramsal bir konu seçmiştim. Bu da beni } \\
\text { daha çok okumaya ve daha fazla araştırmaya yöneltti. Alan geniş olunca bu konuda yapılan } \\
\text { çalışmalar da fazlaydı ve okumayı bitirip yazmaya başlamam çok uzun zamanımı aldı. }\end{array}$ \\
\hline & & $\begin{array}{l}\text { Neslihan: Danışmanım oldukça zor bir tez konusu seçmişti. Dünyada ve ülkemizde çok az } \\
\text { çalışılmış bir konuydu. Yazılı kaynak bulma noktasında çok zorluk yaşamıştım. }\end{array}$ \\
\hline & & $\begin{array}{l}\text { Eren: Çalışacağınız konunun daha önce az çalışılmış olmasının da kendine göre zorlukları } \\
\text { vardı tabi. }\end{array}$ \\
\hline \multirow{7}{*}{ 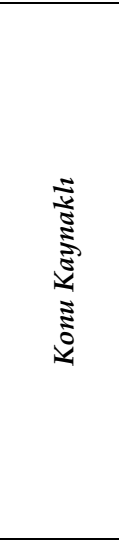 } & \multirow{3}{*}{$\begin{array}{l}\text { Kaynă̆a } \\
\text { Erişim }\end{array}$} & Ayşe: Yetersiz Türkçe kaynaklar. \\
\hline & & $\begin{array}{l}\text { Şükran: Özel bir konu araştırılıyorsa eğer onun ile ilgili ulusal düzeyde kaynak bulma } \\
\text { sıkıntısı en büyük zorluktu. }\end{array}$ \\
\hline & & $\begin{array}{l}\text { Eren: Kaynak bulma konusunda birçok kaynağa internet ortamında ulaşılabilse de } \\
\text { ulaşılamayan kaynakların olması aradığınız basılı yayının okul kütüphanesinde } \\
\text { bulunamaması da önemli zorluklardandı. }\end{array}$ \\
\hline & \multirow{4}{*}{ Çeviri } & Ayşe: Tercüme edilememiş kaynaklar. \\
\hline & & $\begin{array}{l}\text { Şükran: Uluslararası literatürde kaynaklara ulaşıp onların çeviri yapılma konusunda } \\
\text { birtakım sıkıntılarım olmuştu. }\end{array}$ \\
\hline & & $\begin{array}{l}\text { Sezer: Bir başka zorlandığım konuda İngilizcemin çok iyi olmamasından dolayı, çevirisi } \\
\text { olmayan kitap ya da makaleler gibi yabancı kaynakları okumak ve yorumlamaktı. Sürekli } \\
\text { İngilizce öğretmenlerimizden destek aldım. Bu da çok fazla zaman kaybına yol açtı. }\end{array}$ \\
\hline & & $\begin{array}{l}\text { Eren: Yabancı dildeki eserlerin temin edilmesi ve tercüme edilmesini de tez yazım sürecinin } \\
\text { zorlukları arasında sayabilirim. }\end{array}$ \\
\hline 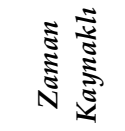 & İş̧ Yükü & Hülya: O kadar çok iş yüküm vardı ki, teze yoğunlaşmak çok zordu benim için. \\
\hline
\end{tabular}




\begin{tabular}{|c|c|c|}
\hline \multirow{4}{*}{  } & & Ali: Saha ziyaretlerinde doğru yorum ve bilgiye ulaşma cabalarının zorluğu. \\
\hline & $\begin{array}{l}\text { Veri Toplama } \\
\text { Araçları }\end{array}$ & $\begin{array}{l}\text { Sezer: Benim tezim nitel bir araştırmaydı. Okul müdürleri ile bire bir görüşme yaptım. Bu } \\
\text { görüşmelerde zaman ve veri kaybı yaşamamak için ses kaydı yapmak istediğim zaman, bazı } \\
\text { okul müdürlerinin rahatsız olduklarını gördüm. Ses kaydı onların doğallığın bozduğunu } \\
\text { düşünüyorum. Bu görüşme için izin alınmasına rağmen okul müdürlerimiz ses kaydından } \\
\text { rahatsız oluyorlar. Bu da verinin tam alınamamasına yol açıor. Yine anket doldurmak } \\
\text { istemeyen, bu işi angarya olarak gören hatta anket doldurmak istemeyip okul idarecilerinin } \\
\text { ricasıyla hatır için anket dolduran öğretmenlerle bile karşılaşmak üzücüydü. }\end{array}$ \\
\hline & $\begin{array}{l}\text { İzin/Randevu } \\
\text { Alamama }\end{array}$ & $\begin{array}{l}\text { Meltem: Bunların dışında, çalışma grubumda bulunan kişilere araştırmanın amacını } \\
\text { anlatarak görüşme için randevu talep etmek sonrasında ses kaydı için kişileri ikna etmek ve } \\
\text { ses kayıtlarını Word ortamına aktarmak beni en çok zorlayan kısımlardı. }\end{array}$ \\
\hline & İzin Süreci & $\begin{array}{l}\text { Ali: Eğer tez konusuna ve kullanılacak ölçme araçlarına karar verildiyse bu çok iyi ama } \\
\text { bunlarla ilgili aşama çok sıkıntıl, etik kurul süreci akabinde Milli Eğitim Müdürlüklerinden } \\
\text { izin alma yazışmalar o kadar uzun sürüyor ki, bu nedenle veri toplama zamanının çok iyi } \\
\text { ayarlanması gerekiyor. }\end{array}$ \\
\hline 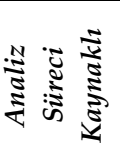 & $\begin{array}{l}\text { İstatistik } \\
\text { Programlart }\end{array}$ & $\begin{array}{l}\text { Şükran: Sosyal bilimlerde yapılan araştırmaların analizlerinde akademik dile sahip olup o } \\
\text { şekilde yorumlanması gerekir bu analizlerin yapılması bağlamında birtakım programlara } \\
\text { çok iyi olacak şekilde hakim olup analizleri yapıp ve sonuçlarına ulaşma kısmında } \\
\text { sıkıntılarım olmuştu. }\end{array}$ \\
\hline
\end{tabular}

Gamze: Sonraki süreçte evdeki sorumluluklar, işteki sorumluluklar haricinde tez danışmanın ile ilgili sorunların hepsinin birleştiği bir aşama da pes etmeden devam edebilme mücadelesi vermek yaşadığım zorluklara örneklerdir.

Leyla: Planlanan takvime uyamadığım için motivasyonum düşüyordu. Süreç sonuçlanana kadar da bu sıkıntıyı hep yaşadım. Çalışırken lisansüstü eğitim almak zaten zor oldu. Bir de tez yazma sürecinde tamamen konsantre olmakta zorlandım. Çünkü öğretmen olduğum için ilgilenmem gereken sınıflar, hazırlamam ve okumam gereken sınavlar, yoğun bir ders ve kurs programım vardı. Bu durumlar da tez yazma sürecimi etkiledi. Bir konuya yoğun bir şekilde odaklanıp yazmaya çalışmak beklediğimden daha uzun sürüyordu. Tam odaklanıp verimli çalışmaya başlayınca iş hayatı araya girip verimimi düşürüyordu. Sadece akademi dünyasıyla ilgilensem eminim daha kısa sürede, daha az stresli ve daha keyifli bir çalışma yürütebilirdim.

Meltem: Benim için en büyük zorluk, iş ile birlikte tez yazmak oldu. Araştırma yapmak için iş yerimden izin almak zor olduğu gibi geceleri tez için uykusuz kalmak ve hafta sonlarını kütüphanede geçirmek yorucuydu.

Ali: Mesai içinde akademik çalışmalara yeterince zaman ayırılamaması ve MEB tarafından sadece sözlü destek verilmesi hiçbir düzenlemenin destekleyici olmaması.

Sezer: Tez yazma sürecinde benim en çok zorlandığım hem iş hem aile hem çocuklar ile tez yazma sürecini beraber götürmemdi. Bu nedenlerden dolayı zaman sıkıntısı çok yaşadım. Hem ders zamanlarında hem de tez yazım aşamasında sürekli koşuşturma ile geçti.

Tablo 3'te görüldüğü üzere danışman alt temasındaki iletişim kodunda bir, baskı kodunda bir, dönüt kodunda ise iki katılımcı düşünceleri dile getirmişlerdir. Konu alt temasında ise tez konusu kodunda dört, kaynağa erişim kodunda üç, çeviri kodunda ise yine dört katılımcı görüşlerini açıklamışlardır. Zaman alt temasında belirlenen iş yükü kodunda ise bir katılımcı görüş sunmuştur. Veri toplama alt temasında veri toplama araçları kodunda iki, izin/randevu alamama kodunda bir ve izin süreci kodunda yine bir katılımcı görüş bildirmişlerdir. Analiz alt temasındaki istatistik programları kodunda bir, kişisel alt temasındaki iş yaşam kodunda ise beş katılımcı düşüncelerini dile getirmişlerdir. Katılımcılar zorluklara ilişkin olarak en çok iş yaşam dengesi kodunda görüş bildirirken bunu tez konusu ve çeviri takip etmiştir.

\section{Tez Sürecinin Hissettirdikleri:}

Tablo 4'te tez sürecinin hissettirdiklerine ilişkin kodlar ve katılımcıların örnek ifadelerine yer verilmektedir. 
Tablo $4^{\prime}$ te görüldüğü gibi tez sürecinde hissedilenlere ilişkin olarak katılımclların dördü olumsuz, dördü karmaşık ve ikisi olumlu hisler kodlarında görüşlerini belirtmişlerdir. Katılımcıların çoğunluğu tez sürecinde yaşanan hislerim olumsuz ya da karmaşık olduğunu bildirmişlerdir.

Tablo 4. Tez Sürecinin Hissettirdikleri

\begin{tabular}{|c|c|}
\hline Kodlar & Katılımcıları Ífadeleri \\
\hline \multirow{3}{*}{ Olumsuz } & Neslihan: Umutsuzluk, çaresizlik ve yetersizlik. \\
\hline & Aydan: Stresli, gergin, yetersiz, yorgun, perişan olma ihtimalim var. \\
\hline & Ezgi: Stresli, melankolik, kaygı dolu, sancilı. \\
\hline \multirow[t]{3}{*}{ Olumlu } & $\begin{array}{l}\text { Leyla: Tez sürecinde hep yazamayacağımı ve bitiremeyeceğimi düşünüyordum. Bu durum da beni iyice } \\
\text { karamsar yapıp ilerlememi zorlaştırdı. Konuların içinde çok kayboldum. Ele aldığım her konuda nerden nasıl } \\
\text { başlayacağımı bilemedim. Bir konu üzerinde yoğunlaşıp yazmaya başlamam çok zamanımı aldı. Sürekli stres } \\
\text { halindeydim. Tezle ilgilenmediğim zaman kendimi suçlu hissettim. Yazmaya başlayıp ilerleyince ve } \\
\text { danışmanımdan da olumlu eleştiriler alınca kendime güvenerek ilerlemeye başladım. Bu da beni biraz olsun } \\
\text { rahatlattı. Yaptığım okuma ve araştırmaların yazıya dökülmesi bir süre sonra beni motive etmeye başladı. Hiç } \\
\text { istemeden çalıştığım zamanlar da oldu. Bitirmem gerektiği için çalışmak zorundaydım. Verdiğim emeğin boşa } \\
\text { gitmesini istemiyordum. Yarıda bırakamazdım. O yüzden hiç istemesem bile kendimi zorladığım dönemler } \\
\text { oldu. Bu yüzden çok sıkıldığım ve bunaldığım günler geçirdim. Ama ilerleme gördükçe kendi kendime motive } \\
\text { oldum ve sona ulaştım. Sürece genel olarak baktığımda başlangıçta karamsarken sona doğru daha } \\
\text { umutluydum. Ancak bitirememe, zamanında yetiştirememe ya da jürinin kabul etmeyeceği korkuları da süreç } \\
\text { içinde hep vardı. }\end{array}$ \\
\hline & $\begin{array}{l}\text { Sezer: Ben tez sürecini iki boyuttan düşünüyorum. Birincisi akademik diğeri sosyal boyutu. Akademik } \\
\text { boyutunda belli bir zamanda istenilen kurallar çerçevesinde tez kitap olarak oluşturuldu. Burada tez } \\
\text { danışmanımın bana sonsuz desteği ve katkısı ile bu süreci rahat aştım. İkincisi olan sosyal boyutunda ise yeni } \\
\text { kişiler tanımak, bu kişilerle sohbet etmek, tekrar üniversite yıllarında olduğu gibi kafede oturup çay içmek bile } \\
\text { keyifliydi. Ben tez yazma sürecinde hem tez danışmanım hem de arkadaş yönünden şanslı olduğumu } \\
\text { düşünüyorum. Bu şans bana tezimi daha rahat oluşturmamı sağladı. }\end{array}$ \\
\hline & $\begin{array}{l}\text { Eren: Genel olarak ifade etmek gerekirse süreçte karşıma çıkan olumsuzlukları yine süreç içinde ortaya } \\
\text { koyduğum somut çalışmalarla ortadan kaldırma duygusu tarif edilemez bir duyguydu. Tez sürecini literatür } \\
\text { tarama kısmından sonra eğlenceli olarak değerlendirmek yanlış olmasa gerek. Çünkü artık kendi } \\
\text { çalışmalarımızın ürününü almaya başladığımız dönem girmiş oluyoruz bir nevi hasat zamanı olmuş oluyor } \\
\text { bizim için. }\end{array}$ \\
\hline \multirow{4}{*}{ Karmaşık } & $\begin{array}{l}\text { Gamze: Bazen özgüveni yüksek, bazen çöküşte kararsız, bazen mücadeleci azimli gibi karmaşık hislerim vardı. } \\
\text { Ama bunların geçici bir olduğunu bilerek tezim bitince yaşayacağım mutluluğu, omuzlarımdaki yükten } \\
\text { kurtulacağımı düşünerek çalıştım ve başardım. }\end{array}$ \\
\hline & $\begin{array}{l}\text { Meltem: Uzun ve dik bir merdivenin basamaklarını tek tek çıkmak gibi. Yorulmak, bazen durup dinlenmek } \\
\text { bazen de bırakmak isteyip geriye dönüp baktığında çıktığın katları görerek devam etmen gerektiğini } \\
\text { düşünmek veya danışman hocanın sana olan inancını düşünerek ve onun motivasyonuyla devam etmek ve en } \\
\text { sonunda keyfine doyulmaz bir mutlulukla yaptıklarına bakıp bunca yolu nasıl geldiğine inanamayıp sonunda } \\
\text { başarmış ve bitirmiş olmanın tadını çıkartmak olarak tarif edebilirim. }\end{array}$ \\
\hline & $\begin{array}{l}\text { Ali: Yoğun yorucu ama başarma hırsının oluştuğu bir dönem. Her şeye rağmen ileriye atılacak bir adımın ilki } \\
\text { olması açısından güzel. }\end{array}$ \\
\hline & $\begin{array}{l}\text { Osman: Öncelikle tezi bitirmiş olduktan sonra özgüven sağladım. Ancak tez yazarken ki süreçte ara ara } \\
\text { yetersizlik duygusuna kapıldım. Genellikle gergin bir süreç olarak geçirdiğimi söyleyebilirim çünkü belirli bir } \\
\text { sürede tamamlanması gereken bir şey olarak algılandığından gerginlik ister istemez yaşanıyor. Diğer şekilde } \\
\text { aşama aşama da özgüven ve başarının sağladığı mutluluğu yaşamaya başladım. Artık bazı şeyleri başara } \\
\text { bileceğimi ve sürdürebileceğime dair kendime olan inancım arttı. }\end{array}$ \\
\hline
\end{tabular}

\section{Tez Sürecine Yönelik Öneriler:}

Tablo 5'te tez sürecinin zorluklarına ilişkin alt tema, kod ve katılımcıların örnek ifadelerine yer verilmektedir. 
Tablo 5. Tez Sürecine Yönelik Öneriler

\begin{tabular}{|c|c|c|}
\hline $\begin{array}{l}\text { Alt } \\
\text { Temalar }\end{array}$ & Kodlar & Katılımcılarn Iffadeleri \\
\hline \multirow{5}{*}{$\underset{\bar{z}}{\Sigma}$} & \multirow{3}{*}{ Merak-ílgi } & $\begin{array}{l}\text { Neslihan: Danışmanları ile birlikte ayrıntılı bir görüşme yapıp kendilerine uygun bir tez } \\
\text { konusu seçsinler. }\end{array}$ \\
\hline & & $\begin{array}{l}\text { Aydan: Kesinlikle üzerinde çalışılan konu ilgi alanı, sevilen bir konu olmalı ki çalışmak } \\
\text { işkenceye dönüşmesin. }\end{array}$ \\
\hline & & $\begin{array}{l}\text { Ezgi: İlgi duydukları, merak ettikleri zevkle çalışabilecekleri bir konu seçimi öncelikli } \\
\text { tavsiyemdir. }\end{array}$ \\
\hline & & $\begin{array}{l}\text { Şükran: Ulusal ve uluslararası literatürde bolca kaynağın olduğu bir konu üzerine } \\
\text { çalışılması kolaylık olacaktır. En önemlisi bol bol okumaların yapılması konuya olan } \\
\text { hâkimiyeti arttıracağından ileriki safhalarda işlerini kolaylaştıracaktır. }\end{array}$ \\
\hline & Popülerlik & $\begin{array}{l}\text { Leyla: Öncelikle konu üzerinde dikkatlice düşünüp araştırmalarını öneririm. Çok çalışılmış } \\
\text { bir konu, çalışması kolay gibi görünebilir ancak kaynak bakımından bir okyanusta } \\
\text { çırpınmaya benziyor. Öncelikle konuya karar vermeden önce kaynakları kapsamlı bir } \\
\text { şekilde gözden geçirmelerini öneririm. Yani tezde evet her şeyi ele almak zorunlu değil } \\
\text { ancak nitelikli bir ürün ortaya koymak isteniyorsa ele alınan konunun her açdan } \\
\text { incelenmesi gerekecektir. Bu nedenle az çalışılmış bir konu seçmek daha avantajlı olabilir. } \\
\text { Ya da araştırılmak istenen konunun çok çalışılmamış bir boyutu ele alınabilir. }\end{array}$ \\
\hline \multirow{3}{*}{ 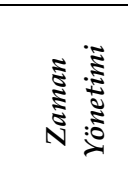 } & \multirow[b]{2}{*}{$\begin{array}{l}\text { Çalışma } \\
\text { Takvimi }\end{array}$} & Neslihan: Çalışma takvimi oluşturup bu takvime uymaya çalısssınlar. \\
\hline & & $\begin{array}{l}\text { Sezer: Tez sürecinden önce bir yol haritası çizmeli. Neyi zaman nasıl yapacağına karar } \\
\text { vermeli. Hangi ay hangi bölümü oluşturacağın önceden belirlemeli. }\end{array}$ \\
\hline & Planlama & $\begin{array}{l}\text { Ali: Hayatınızın akışını etkileyecek bir ciddi problemler zinciri yoksa zamanı iyi planlayın } \\
\text { süresi içinde tüm çalışmalarınızı tamamlayın. }\end{array}$ \\
\hline \multirow{3}{*}{  } & Seçim & $\begin{array}{l}\text { Aydan: Danışmanınızı özgürce, iletişim kurabildiğiniz, dilini anladığınız, sizi anladığını } \\
\text { düşündüğünü birini özgürce seçebilmek önemli. Eğer istediğiniz öğretim üyesi ile } \\
\text { çalışmanıza izin verilmeyen durumlar olursa bu süreci içinden çıkılmaz bir hale } \\
\text { dönüştürebiliyor. }\end{array}$ \\
\hline & \multirow[t]{2}{*}{ İletişim } & $\begin{array}{l}\text { Meltem: İletişim o kadar önemli ki Danışmanınıza ihtiyaç duyduğunuzda ulaşabilmeniz. } \\
\text { Veya tezin herhangi bir yerinde yetersiz, eksik, başarısız hissettiğiniz noktada sizi rahatsız } \\
\text { edenin, neyi başaramadığınızı hatta neden başaramadığınızı açık şekilde dile } \\
\text { getirebileceğiniz bir danışman. İletişimi mutlaka iyi oluşturmaya çalışılmalı. }\end{array}$ \\
\hline & & $\begin{array}{l}\text { Sezer: Baskı kurarak emrivaki şekilde bir iletişimin kimseye yararı olmayacaktır. Mutlaka } \\
\text { danışmanla etkili iletişim kurma yolları bulunmalıdır. }\end{array}$ \\
\hline \multirow{4}{*}{ 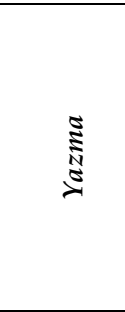 } & $\begin{array}{l}\text { Yazım } \\
\text { Kılavuzu }\end{array}$ & $\begin{array}{l}\text { Neslihan: Tez yazım kılavuzunu iyi okusunlar. Sonra ya tezin bitmesine yakın ya da jüride } \\
\text { ya da teslim edeceğiniz sırada enstitüden sürekli olarak düzeltme uyarısı alıyorsunuz. }\end{array}$ \\
\hline & \multirow[t]{2}{*}{ Teknik Destek } & $\begin{array}{l}\text { Leyla: Eğer bilgisayardaki basit programları kullanmada bile sorun yaşıyorsanız, çok çeşitli } \\
\text { bölümler, tablolar, şekiller, grafikler sizi tez yazımı esnasında oldukça zorlayacaktır. Bu } \\
\text { nedenle belki bu işi iyi bilen, yapan kişilerden destek alınmalı. }\end{array}$ \\
\hline & & Osman: İçindekiler kısmını bile yapmakta zorlandığım anlar oldu. \\
\hline & $\begin{array}{l}\text { Yardımcı } \\
\text { Programlar }\end{array}$ & Neslihan: EndNote gibi yardımcı programlara başvurulabilir. \\
\hline \multirow[b]{5}{*}{ 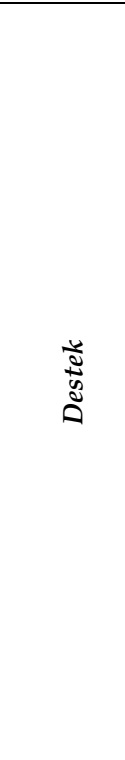 } & \multirow{3}{*}{ Akran } & $\begin{array}{l}\text { Ayşe: Arkadaşlarını iyi seçsinler. Herkesle arkadaş olmasınlar özellikle ders döneminde } \\
\text { moral bozuyorlar. }\end{array}$ \\
\hline & & $\begin{array}{l}\text { Ezgi: Tez sürecinde destek alabileceği, motive olabileceği, bu süreci yaşayan kişilerle } \\
\text { iletişim kurmak. }\end{array}$ \\
\hline & & $\begin{array}{l}\text { Sezer: Tez yazım aşamasında tezi mutlaka bir arkadaşı ile paylaşmalı, gözünden kaçan } \\
\text { bölümleri başkası daha rahat görebilir. }\end{array}$ \\
\hline & & Şükran: Eğer yüksek lisans öğrencileriyse danışman seçimine çok dikkat edilmesi gerekir. \\
\hline & Danışman & $\begin{array}{l}\text { Leyla: Ayrıca tez yazma sürecinde danışmanın etkisi de çok büyük. Ben çalışmamı çok } \\
\text { erteledim ama danışmanım vazgeçmedi. Bu yüzden öğrencilerin gerçekten kendilerini } \\
\text { destekleyen danışmanlarla çalışmasını öneririm. Tez yazmak zaten stresli bir süreç. O } \\
\text { yüzden bir de danışmanın aşırı baskı yapması ya da sürekli olumsuz eleştirilerde } \\
\text { bulunması öğrenciyi zor duruma sokabilir. Eğer çalışma stili uymuyorsa değiştirme } \\
\text { imkânları varsa danışmanını değiştirsinler. Öğrenciler ne yapmak istediklerini de } \\
\text { danışmanlarıyla açıkça konuşabilmeliler. Sonuçta ortaya çıkan ürün öğrencinin gelişimine } \\
\text { katkı sağlayacak ve ilerdeki çalışmalarına temel oluşturacak. Bu yüzden danışmanın } \\
\text { isteklerinden çok öğrencinin istekleri önemli olmalı. Ama bu sadece öğrencinin isteği değil } \\
\text { danışmanla beyin fırtınası yaparak şekillendirilmeli. Bence tez yazma sürecinin en önemli } \\
\text { faktörü danışmanla olan iletişim. İşi zorlaştıran da kolaylaştıran da danışman oluyor Tez } \\
\text { yazma süreci zorlu bir süreç. Ancak danışmanla sağlıklı iletişim, planlama ve kendine } \\
\text { güvenle üstesinden kolaylıkla gelinebilecek bir süreç. }\end{array}$ \\
\hline
\end{tabular}




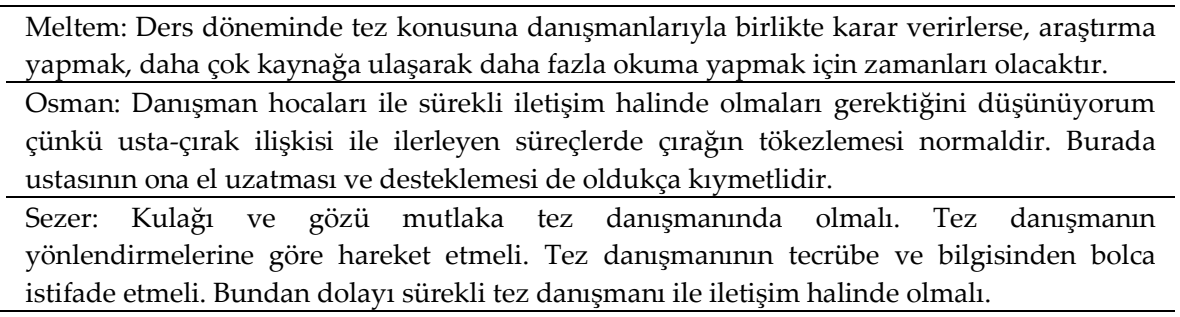

Tablo 5’te görüldüğü gibi konu alt temasında konu kodunda dört katılımcı görüş bildirmiştir. Popülerlik kodunda ise görüş bildiren iki katılımcı bulunmaktadır. Zaman yönetimi alt temasında yer alan çalışma takvimi kodunda iki, planlama kodunda ise bir katılımcı görüş bildirmektedir. Danışman alt temasında yer alan seçim kodunda bir, iletişim kodunda iki katılımcı görüş bildirmektir. Yazma alt temasında yazım kılavuzunda bir, teknik destek kodunda iki, yardımcı programlar kodunda bir katılımcı görüş sunmuştur. Son alt tema olan destekte ise beş kişi danışman kodunda görüş bildirmişlerdir. Katılımcıların en çok vurguladığı öneri danışman desteği olurken en az vurgulanan öneri tez tazım kılavuzu, teze yazımına yardımcı programlar, danışman seçimi ve zamanı planlama olmuştur.

\section{Tartışma, Sonuç ve Öneriler}

$\mathrm{Bu}$ araştırmada eğitim yönetimi alanında yüksek lisansını tamamlayan mezunların lisansüstü eğitim yapma nedenlerine, tez sürecinin kazandırdıklarına, zorluklarına, bu süreçte yaşanan hislere ve tez sürecine ilişkin öğrencilere önerilere ilişkin görüşlerini ortaya çıkarmaya amaçlanmıştır.

Eğitim yönetimi alanında yüksek lisansını tamamlayan katılımcıların çoğunluğu lisansüstü eğitim yapma nedenlerinin mesleki ve kişisel gelişim olduğunu ifade etmişlerdir. Bir kısmı da akademik çevre ile etkileşim kurarak böyle bir çevrede yer almak ve kariyerde ilerlemek amacı ile lisansüstü eğitim yaptıklarını söylemişlerdir. Katılımcılar alana ilişkin teorik bilgileri de detaylı bir şekilde derinlemesine öğrenerek uygulama ile bağlantı kurma, kendini yenileyebilme alanda alacağ lisansüstü eğitim ile bulunduğu konumda uzmanlaşma konularına vurgu yapmışlardır. Ayrıca, Araştırmanın bu bulgusu Koşar, Er ve Kılınç'ın (2020), Alabaş, Kamer ve Polat'ın (2012), Kılınç, Karahalilöz ve Bektaş'ın (2020), Serin ve Ergin-Kocatürk'ün (2019), Maviş-Sevim ve Akın'ın (2021), Kahraman ve Tok'un (2016), Aktan'ın (2020), İlter'in (2019), Aküzüm (2016) araştırma bulguları ile de kısmen benzerlik göstermektedir. Söz konusu araştırmalarda da katılımcıların lisansüstü eğitim alma nedenleri kültürel gelişim, akademik ortama temayüz etme, ekonomik katkı ve yeni fikir ve düşüncelerle karşılaşma, alan bilgisini genişletme, okulda yapılan öğretimi geliştirme, alana daha fazla hâkim olma, kariyer gelişimi, yönetici olma isteği şeklinde belirlenmiştir. Bu açlardan ele alındığında eğitim yönetimi alanında lisansüstü eğitim yapmak isteyen öğretmenlerin veya okul yöneticilerinin en önemli nedenlerinden birisinin kendilerini geliştirmek olduğu ifade edilebilir. Özellikle uygulama konusunda engin tecrübelere sahip öğretmen ve yöneticiler sahip oldukları 
deneyimlerini teori ile bütünleştirerek daha etkili mesleki özellikler sergileyebileceklerini düşünüyor olabilirler. Özellikle Öğretmen Strateji Belgesi ve 2023 Eğitim Vizyon Belgesinde de vurgulandığ1 üzere öğretmenlerin niteliklerinin artırılması, sürekli mesleki gelişimin sağlanması önem teşkil etmektedir. 2023 Vizyon Belgesinde insan kaynakları bağlamında Yükseköğretim Kurulu (YÖK) ile iş birliği ve koordinasyon çerçevesinde hem okul müdürleri hem de öğretmenlerin mesleki gelişimlerinin lisansüstü dereceye dayalı olarak yapılandırılması amaçlanmıştır.

Eğitim Yönetimi alanında yüksek lisansını tamamlamış olan katılımcıların çoğunluğu tez sürecinin kendilerine akademik anlamda, bireysel olarak ve yeni çevre kazanma bağlamında getirileri olduğu konusuna değinmişlerdir. Katılımcıların çoğunluğu alanyazını etkili bir şekilde tarama fırsatı yakaladıklarını bunun da kendilerine bilimsel yayın okuma alışkanlığı kazandırdığını vurgulamışlardır. Tez yazma sürecinde akademik yazma becerisi ve okuduklarını sentezleme becerisi yine vurgulanan konular olmuştur. Bununla beraber katılımcıların alana ve mesleklerinin teorik boyutuna ilişkin farkındalıklarının arttığı, analiz yapabilme becerisinin kazanıldığı, kişilerin tez yazma sürecinde planlama yapabilme ve bu plana uyma konusunda deneyim kazandıkları, sürekli okumanın, yeni bilgiler elde ederek çevre ile de etkileşimin katkısı ile yeni perspektif elde edilmesi araştırmanın diğer dikkat çekici bulguları arasında yer almaktadır. Katılımcılar yüksek lisans ve özellikle tez sürecinde alandaki diğer üniversite, bölüm, ana bilim dalları hocaları ile etkileşimlerinin bu sürece farklı bakış açısı kazandırması bağlamında önemli olduğunun altını çizmişlerdir. Araştırmanın bu bulgusu Kan ve Gedik'in (2016) yapmış oldukları araştırma bulguları ile kısmen örtüşmektedir. Araştırmada tez sürecinin akademik yazma ve bilimsel söylem konularında katkı sağladığı belirlenmiştir. Ayrıca Serin ve Ergin-Kocatürk'ün (2019) araştırma bulgusu ile de bilimsel okuryazarlık, farklı bir bakış açısı kazandırma, eleştirel ve analitik düşünme ve kişisel gelişim bulguları açısından da bu bulgu benzerlik göstermektedir. Aküzüm (2016) yapmış olduğu çalışmasında eğitim yönetimi programı bağlamında lisansüstü eğitim ile kazanılmak istenen davranışların arasında lisansüstü eğitim sürecinin sonunda öğrencilerin başarılarını artırabilecek ve alanlarına katkı sunmalarına imkân sağlayabilecek tutum ve davranışları edinme, "bilimsel metotları kullanabilen", "topluma katkı sağlayabilen" ve "kurumunda lider olabilme, "ulusal bilim politikasına katkı sağlayabilen”, "bilim kültürünü okula taşıyabilen” ve "öğretmen ve öğrencilere rol model olabilme olarak belirlemişlerdir. Bu bağlamda Aküzüm'ün (2016) araştırma bulguları da çalışma bulgularını destekler niteliktedir. Buradan hareketle yoğun bir çalışma temposu gerektiren tez sürecinin bu süreci yaşayanlara belirli bir konuda bir araştırmanın nasıl yapılabileceği, bilimsel yayınlara nasıl ulaşacağı ve kendi konusuna katkı sağlayacak bilimsel yayını diğerlerinden nasıl ayırt edeceğine ilişkin önemli katkıları olduğu ifade edilebilir. Elbette bir araştırma sürecinin nasıl başlayacağı ve yürütüleceğine ilişkin ders döneminde çeşitli dersler okutulmaktadır ancak öğrenciler 
bireysel olarak tez sürecinde bunu deneyimlemektedirler. Aynı zamanda alanyazın taraması, sentezleme, yayın okuma sıklığı da ulaşılan yayınlara eleştirel bir bakış açısı ile yaklaşma konusunda katılımcılara bakış açısı kazandırmıştır. Elbette bu sürecin bir okuma, araştırma, sentezleme, analiz, veri toplama gibi bazı aşamalardan oluştuğunu bu bağlamda kişilerin de çeşitli kongrelere seminerlere vb. katılımlarını da artırdığını da göz önünde bulundurulduğunda kişilerin süreçte alandan yeni öğretim elemanları, öğrenciler ile etkileşimde bulunabileceği bunun da akademik etkileşime önemli oranda katkısı olacağı vurgulanabilir.

Araştırmanın bir diğer sonucu katılımcıların tez sürecinde yaşadığı zorluklara ilişkindir. Katılımcıların çoğunluğu tez sürecinin en büyük zorluğunun iş yaşam dengesini sağlamak olduğu konusunda hemfikirdirler. Tez sürecinde hem bir kurumda görev yapıyor olmak, hem aile yaşantısında farklı rollere sahip olmak iş, tez yazımı ve aile üçgeninde kişileri zorlayabilmektedir. Nitekim katılımcılarda görev yaptıkları kurumdan izin almada, evde eşin çocukların bu süreci destekleme konusunda yetersiz olmaları teze adapte olarak çalışmaya vakit ayırmada problemler yaşadıklarını ifade etmişlerdir. Katılımcıların büyük bir kısmının aslında sürecin başında tez konusu seçerken zorlandıkları bulgusu oldukça dikkat çekicidir. Alana katkı sağlayacak yeni bir konu, üzerinde daha önce çalışılmamış ya da az çalışılmış bir konu seçme zorunda olduklarını düşünmeleri, danışmanın kendisinin öğrencinin yerine tez konusunu seçmesi ve konuda ısrarcı olması bu bağlamda en çok dile getirilen zorluklar olmuştur. Özellikle katılımcıların bir kısmı da neyi nasıl ele alacakları konusunda hem kararsız hem de yetersiz hissettiklerini, bu nedenle de kapsamlı bir şekilde bütüncül resmi göremediklerini, neredeyse sadece süreci tamamlamak amacı ile kendilerine uygun olmayan konularla vakit kaybı yaşadıklarını belirtmişlerdir. Zorluklara ilişkin vurgulanan bir diğer önemli nokta ise çeviri ve kaynağa ulaşım konusunda yaşanan zorluklardır. Lisansüstü eğitime başlarken belirli bil dil puanı gerektirse de katılımcılar yabancı dilde bir yayın okuma, anlama, analiz etme, sentezleme ve kendi çalışmalarına entegre etme konusunda zorlanmaktadırlar. Bu nedenle de kaynağa erişim konusu kişileri zorlamaktadır. Tez konusuna ilişkin yaşanan deneyimlere ek olarak danışman ile yaşanan zorluklar da katılımcılar tarafından çoğunlukla dile getirilmiştir. Danışmanla etkili iletişim kurma, danışmanın ulaşılabilir olmaması, teze zamanında dönüt vermemesi gibi çeşitli sıkıntılar bulunmaktadır. Araştırmanın bu bulgusu Aslan (2010), Bakioğlu ve Gürdal, 2001, Kan ve Gedik, 2016) araştırma bulguları ile kısmen benzerlik göstermektedir. Söz konusu araştırmalarda da uluslararası literatürden yararlanmak adına yabancı dilde yazılmış bilimsel kaynakları okuma, anlama, çevirisini yaparak çalışmalarına katma konusunda zorluklar yaşandığı belirtilmiştir. Arastaman, Uslu, Arslan ve Gülsoy-Kerimoğlu'nun (2020) Eğitim Yönetimi alanındaki doktora öğrencileri ile tüm sürece ilişkin yürüttükleri çalışmalarında da benzer şekilde yabancı dil yetersizliğinden kaynaklanan güçlükler ve aynı zamanda danışman ile etkileşimin yeterli olmaması 
danışman desteği eksikliği sorunlar arasında vurgulanmıştır. Aynı şekilde tez konusunun seçimi ve çalışmaya ilişkin kaynaklara ulaşma konusundaki zorluklar Balı ve Dönmez'in (2018) araştırma sonuçları ile benzerlik göstermektedir. Her ne kadar Balı ve Dönmez'in (2018) araştırması doktora öğrencileri ve onların tez yazım süreci bağlamında olsa da lisansüstü eğitimde yüksek lisans aşamasında da benzer sorunların yaşandığı görülmektedir. İş yaşam dengesi kurmaya ilişkin bu araştırmada ortaya konan zorluklara ilişkin olarak yine Yılmaz vd.'nin (2016) yapmış oldukları araştırmada da lisansüstü öğrencilerin mesleki iş yükünün ve aile içi sorumluluklarının fazla olması nedeniyle iş-aile-yaşam dengesini sağlayamadıkları, bunun sonucunda ise tezden uzaklaşma, tez sürecini uzatma gibi yeni sorunların ortaya konduğu belirtilmiştir. Yine aynı çalışmada bu araştırmanın da zamana ilişkin yaşanan zorluklar bulgusuna benzer şekilde tez yazma sürecinde zamanını yönetemeyen lisansüstü öğrencilerin tezlerini yazamadıkları ve bu nedenle tez yazım sürelerinde kaytarma davranışı sergiledikleri görülmektedir. Danışmanla iletişim ve süreci beraber etkili şekilde yürütme konusunda ortaya çıkan bulguyu Boufeldja ve Bouhania'nın (2020) da araştırma bulgusu desteklemektedir. Bu çalışmada danışmanın tez sürecindeki desteğinin az olmasının, dönütlerinin zamanında iletilmesinin, süreçte öğrencilerin kendi başlarının çaresine bakma durumunda bırakılmalarının süreci etkilediği sonucuna ulaşılmıştır. Bu araştırmada ortaya konan tez konusu seçimindeki zorluk ve konuya ilişkin yeterli kaynak bulma ve çeviri ile ilişkili olarak Puspita (2019) çalışması da benzer sonuçları ortaya koymuştur. Puspita'nın (2019) çalışmasında da katılımcılar hem tez konusu seçiminde hem de bulunan kaynakların ana dile çevriminde sıkıntılar yaşadıklarını belirtmişlerdir. Lestari'nin (2020) de bu çalışmanın sonuçlarına benzer olarak çalışmasında öğrencilerin tez yazarken karşılaştıkları güçlükler zaman yönetimi, araştırma metodolojisi, araştırma konusu ve danışman ile iletişim, intihal, öğrencilerin motivasyonu şeklinde belirlemiştir. Swarni (2016) çalışmalarında bu sürecin en büyük zorluğunun öğrencilerin literatür taraması bölümünde teze uygun ilgili kaynak ve kaynakları bulamamaları olduğunu bu zorluğu ise giriş bölümünün yazımında araştırmanın arka planının yazılması konusunda fikir eksikliği, araştırma sonucunun sunulması, yöntem yazımında teze uygun yöntemin belirlenmesi ve sonuç bölümünde araştırmanın özetini içeren kısa cümleler oluşturmak takip etmektedir. Tüm bunların ışığında tez sürecinin kişilere getirileri yanında oldukça zor aşamaları olduğu da görülmektedir. Öncelikle genelde lisansüstü eğitim ve özelde tez yazımı bu süreçte yer alan kişileri özellikle iş yaşam dengesi bağlamında oldukça fazla etkilemektedir. Öğretmenlerin çoğu okulda ders yüklerinin fazla olduğunu belirtmişlerdir; bu bağlamda okulda geçirdikleri sürenin uzun olması, iş yükü, kurumdan araştırmaya vakit ayırmak için izin almada karışlarına çıkan engellerden kurumsal olanlardır. Bireysel engeller arasında ise de özellikle çocukları olan katılımcıların onların sorumluluğunun daha da artması, eşlerin sürece destek olmaktan uzak oluşlarının bulunduğu söylenebilir. Tez konusuna karar verme aşamasında kişilerin 
zorlandıkları göz önünde bulundurulduğunda bunun nedenlerinden birisinin ders dönemini başarı ile tamamlama kaygısı nedeni ile süreçte merak uyandıran, ilgi duyulan konuların fark edilmemesi olabilir. Konu seçimine gelindiğinde ise kişiler neyi, nasıl çalışılabileceklerine ilişkin bir çıkmaz yaşayabilmektedir. Danışman konusunda ise öğrencilerin diledikleri tez danışmanı ile çalışamama durumları danışman ve öğrenci arasında iletişim kopukluklarına sebep olabilmekte bu da süreci hem yavaşlatmakta hem de beklenen performans sergilenmemektedir.

Tez sürecinde hissedilenlere ilişkin olarak katılımcıların olumlu hislerden çok olumsuz ve karmaşık olarak hislerini ifade etmeleri oldukça düşündürücüdür. Süreçte çoğunlukla zamanında yetiştirememe, jüride başarısız olma kaygısı, sadece bitirmek zorunda olunduğu için süreci devam ettirme, yazmaya bir türlü başlayamama ve başladıktan sonra da konular arasında dağılma gibi sebeplerle katılımcılar endişeli, umutsuz, melankolik, çaresiz, yetersiz yorgun ve gergin hissettiklerini ifade etmişlerdir. Karmaşık duygular yaşayan katılımcılar ise motivasyon kaybı yaşadıklarında danışmanlarının desteği, başarılı olma ve süreci tamamlama düşüncesi, uzun ve dik bir merdiven tırmanmak gibi ama sonunda başarı ve zafer olduğuna inanılması şeklinde duygularını ifade etmişlerdir. Her ne kadar doktora yeterlik sınavına ilişkin olsa da Gelmez-Burakgazi ve Yıldırım'ın (2016) yapmış oldukları çalışmanın sonuçları da kısmen bu araştırmanın olumsuz hislere ilişkin sonucu ile benzerdir. Lisansüstü eğitimde ders süreci, yeterlik, tez aşaması gibi farklı aşamalar bulunmaktadır ama her aşama kendi özellikleri dâhilinde öğrencilerde farklı hislere neden olmaktadır, ancak Gelmez-Burakgazi ve Yıldırım'ın (2016) da çalışmalarında da bir sınav endişesi olması nedeni ile katılımcıların stres, özgüven eksikliği, endişe gibi duyguları dile getirdikleri belirlenmiştir. $\mathrm{Bu}$ açılardan ele alındığında kişilerin öncelikle motivasyon düzeylerinin ve bu motivasyonu etkileyen kariyerde yükselme şansı, akademik hayata geçiş yapma fırsatı, çocuklarına rol model olma isteği, yeni bir çevrede öğrenmeyi sürekli kılarak kendini yenilenme şansı, lisansüstü eğitime giriş aşamasını akabinde ders aşamasını tamamlayıp sona doğru yaklaşıldığı ve başarıya az kaldığı düşüncesi tez yazım aşamasında danışmanın desteği, veri toplama sürecinin başarılı ilerlemesi gibi süreçte kişileri mutlu eden ve sürece olumlu anlamlar yüklemlerine aksi durumlar is karmaşık ve olumsuz hislere sebep olmuş olabilir.

Katılımcıları tez sürecinde olan ya da bu süreci yaşayacak olanlara önerilerinde tez konusunu çoğunlukla vurgulamaları önemli bir bulgudur. Nitekim katılımcıların tez sürecinin en önemli zorluğunu konu ile ilişkilendirmesi nedeniyle önerilerde de tez konusunu öncelikli vurgulamışlardır. Çok popüler olan konuların da zaman zaman orijinal kaynaklarına ulaşma konusunda sıkıntı yaşanabileceği bu nedenle sadece popüler olduğu için çalışılmaması gerekliliği belirtilmiştir. Ayrıca tezin şekilsel yazımında yetersiz kalınan noktada teknik destek almanın önemi, danışman ile etkili bir iletişim ağı kurmanın, planlamaya ve çalışma takvimi oluşturmanın önemine değinilmiştir. Holmes, 
Robinson ve Seay (2010) öğrenme hedeflerini takip eden ve benimseyen öğrencilerin akademik başarıya giden yolda daha derin bilişsel stratejiler kullandıkları sonucuna varmışlar; akademik görevleri yerine getirmede dikkat dağıtıcı tüm unsurlardan kaçınmanın önemine vurgu yapmışlardır. $\mathrm{Bu}$ öğrenciler, tez tamamlama yönündeki ivmelerini sürdürebilir ve tez tamamlanana kadar kendi kendilerini izleyebilirler. Buradan hareketle tez sürecini birebir deneyimleyen ve bu süreci tamamlamış kişilerin önerilerinin önemsenmesi gerekliliği ve sürece başlayacak olan kişiler için bir yol haritası olabileceği ifade edilebilir.

\section{Kaynaklar}

Aktan, O. (2020). Öğretmenlerin kariyer gelişimi açısından lisansüstü eğitimin değerlendirilmesi. Yükseköğretim ve Bilim Dergisi, 10(3), 596-607. doi: 10.5961/jhes.2020.419

Aküzüm, C. (2016). Okul yöneticilerinin ve öğretmenlerin eğitim yönetimi programı bağlamında lisansüstü eğitime bakış açlarının incelenmesi. EKEV Akademi Dergisi, 20(67), 85-108.

Alabaş, R., Kamer, T. \& Polat, Ü. (2012). Öğretmenlerin kariyer gelişimlerinde lisansüstü eğitim: Tercih sebepleri ve süreçte karşılaştıkları sorunlar. e-Uluslararası Eğitim Araştırmaları Dergisi, $3(4), 89-107$.

Arastaman, G., Uslu, O., Arslan, S. Y. \& Gülsoy-Kerimoğlu, P. N. (2020). Eğitim yönetimi alanında doktora öğrencisi olmak: Lisansüstü öğrencilerin bakış açısından fenomenolojik bir inceleme. Eğitimde Nitel Araştırmalar Dergisi, 8(4), 1323-1346.

Arı, E., Pehlivanlar, E. \& Çömek, A. (2005). Lisansüstü eğitimi öğrencilerinin gördükleri eğitim hakkındaki beklentileri ve görüşlerinin belirlenmesi. Dokuz Eylül Üniversitesi Buca Eğitim Fakültesi Dergisi (Özel Sayı- 1): Lisansüstü Eğitim, 17, 231- 235.

Arıcı, H. (1997). Bilim insanı yetiştirme: lisansüstü eğitim ve sorunları. Ankara: Türkiye Bilimler Akademisi Bilimsel Toplantı Serileri 7: Bilim İnsanı Yetiştirme, Lisansüstü Eğitim.

Aslan, C. (2010). Türkçe eğitimi programlarında lisansüstü öğrenim gören öğrencilerin akademik özyeterliklerine ilişkin görüşleri. Mehmet Akif Ersoy Üniversitesi Ĕ̆itim Fakültesi Dergisi, 10(19), $87-115$

Bahçeci, F. \& Ușengül, L. (2018). Yüksek lisans ve doktora öğrencilerinin tez konusu belirleme kriterlerinin incelenmesi. Turkish Journal of Educational Studies, 5(2), 85-96.

Bakioğlu, A. \& Gürdal, A. (2001). Lisansüstü tezlerde danışman ve öğrencilerin rol algıları: Yönetim için göstergeler. Hacettepe Üniversitesi Eğitim Fakültesi Dergisi, 21(1), 9-18.

Balcı, A. (2008). Türkiye'de eğitim yönetiminin bilimleşme düzeyi. Kuram ve Uygulamada Eğitim Yönetimi, 54, 181-209. 
Balı, O. \& Dönmez, B. (2018). Eğitim bilimleri anabilim dalı doktora öğrencilerinin karşılaştıkları problemler ve çözüm önerileri. İnönü Üniversitesi Eğitim Fakültesi Dergisi, 19(3), 284-309.

Boufeldja, B. \& Bouhania, B. (2020). A qualitative inquiry into the difficulties experienced by Algerian EFL Master students in thesis writing: 'language is not the only problem'. Arab World English Journal (AWEJ), 11(2), 243-257.

Büyüköztürk, Ş., Kılıç-Çakmak, E., Akgün, Ö. E., Karadeniz, Ş. \& Demirel, F. (2015). Bilimsel araştırma yöntemleri. Ankara: Pegem Akademi.

Çakar, Ö. (1997). Fen bilimleri alanında bilim adamı yetiştirme: Lisansüstü eğitim. Ankara: TÜBA.

Gelmez-Burakgazi, S. \& Yıldırım, A. (2017). Journey into doctoral candidacy: A grounded theory study of doctoral qualification exam process. Croatian Journal of Education, 19(1), 63-92.

Holmes, B. D., Robinson, L. \& Seay, A. D. (2010). Getting to finished: Strategies to ensure completion of the doctoral dissertation. Contemporary Issues In Education Research, 3(7), 1-8.

İlter, İ. (2019). Lisansüstü Eğitime Yönelik Tutum Ölçeği'nin Türk kültürüne uyarlanması ve psikometrik özelliklerinin incelenmesi. Elementary Education Online, 18(1), 263-284.

Kahraman, Ü. \& Tok, T. N. (2016). Eğitim yönetimi denetimi planlaması ve ekonomisi lisansüstü öğrencilerinin aldıkları eğitim hakkındaki görüşleri. Uşak Üniversitesi Sosyal Bilimler Dergisi, 9(1), $147-164$

Kan, M. O. \& Gedik, F. N. (2016). Türkçe eğitimi alanında yüksek lisans tezi tamamlayanların akademik yazma ve tez oluşturma sürecine ilişkin görüşleri. Yükseköğretim ve Bilim Dergisi, 6(3), 402-408.

Karaman, S. \& Bakırcı, F. (2010). Türkiye'de lisansüstü eğitim: Sorunlar ve çözüm önerileri. Sosyal Bilimler Araştırmaları Dergisi, 2, 94-114.

Karakütük, K. (1989). Türkiye'de lisansüstü öğretim, sorunları ve çözüm önerileri. Ankara Üniversitesi Eğitim Bilimleri Fakültesi Dergisi, 22(1), 505-528.

Kılınç, A. Ç., Karahalilöz, O. \& Bektaş, F. (2020). Lisansüstü öğrenim görmek: öğretmen deneyimleri üzerinden fenomenolojik bir çözümleme. Uluslararası Türkçe Edebiyat Kültür Eğitim Dergisi, $9(4), 1755-1774$

Koşar, D., Er, E. \& Kılınç, A. Ç. (2020). Öğretmenlerin lisansüstü öğrenim görme nedenleri: Nitel bir araştırma. Mehmet Akif Ersoy Üniversitesi Eğitim Fakültesi Dergisi, 53, 370-392.

Lestari, D. M. (2020). An analysis of students' difficulties in writing undergraduate thesis at english education program of Muhammadiyah University of Bengkulu. Journal of English Education and Applied Linguistics, 9(1), 17-29. 
Maviş-Sevim, F. Ö. \& Akın, U. (2021). Öğretmenlerin mesleki gelişimlerinde lisansüstü eğitimin rolü: mezun olmak yeterli mi? Ĕğtim ve Bilim, 46(207), 483-510.

Oruç, Ş. \& Ulusoy, K. (2008). Sosyal bilgiler öğretimi alanında yapılan tez çalışmaları. Selçuk Üniversitesi Ahmet Keleşoğlu Eğitim Fakültesi Dergisi, 26, 121-132.

Örücü, D. \& Şimşek, H. (2011). Akademisyenlerin gözünden Türkiye'de eğitim yönetiminin akademik durumu: Nitel bir analiz. Kuram ve Uygulamada Eğitim Yönetimi, 17(2), 167-197.

Puspita, C. (2019). Factors affecting students' difficulties in writing thesis: A mixed-methods research at eighth semester of English study program in IAIN curup. https://jurnal.unimus.ac.id/index.php/ELLIC/ article/view/4683 sayfasından erişilmiştir.

Serin, H. \& Ergin-Kocatürk, H. (2019). Eğitim yönetimi yüksek lisans öğrencilerinin eğitim sürecine dair deneyimleri. Eğitimde Nitel Araştırmalar Dergisi, 7(2), 495-513.

Sevinç, B. (2001). Türkiye'de lisansüstü eğitim uygulamaları, sorunlar ve uygulamalar. Dokuz Eylül Üniversitesi Eğitim Fakültesi Dergisi, 34(1), 25-40.

Swarni, B. R. (2016). Student's problem in writing thesis: Case study at English department Mataram university. http://eprints.unram.ac.id/11713/1/E1D\%20111\%20019.pdf sayfasından erişilmiştir.

Yıldırım, A. \& Şimşek, H. (2011). Sosyal bilimlerde nitel araştırma yöntemleri. Ankara: Seçkin.

Yılmaz, N., Doğanalp, S. \& Varol-Durmaz, D. (2016). Lisansüstü öğrencilerde tezden kaytarma davranışları. Süleyman Demirel Üniversitesi Sosyal Bilimler Enstitüsü Dergisi, 3(25), 205-228.

YÖK. (2010). Türkiye yükseköğretim yeterlilikler çerçevesi (TYYÇ). http://tyyc.yok.gov.tr/?pid=20) sayfasından erişilmiştir.

YÖK. (2016). Lisansüstü eğitim ve öğretim yönetmeliği. http://www.yok.gov.tr/documents/18755141/ 21995093/10 lisansustu egitim ve ogretim y\%C3\%B6netmeligi.pdf sayfasından erişilmiştir.

\section{Extended Summary}

The aim of this research is to examine the views of those who have completed their master's degree in the field of educational administration on the thesis process. In line with this main purpose, answers were sought for the following sub-objectives; (i) What are the views of those who have completed their master's degree in the field of educational administration on the reasons for doing postgraduate education?, (ii) What are their opinions about the thesis process?

The qualitative research method was preferred in order to get detailed and in-depth opinions of the participants on the subject. The research is in the phenomenological design. The case examined in this study is the experiences of people who have completed their master's degrees in the field of educational administration regarding the thesis process, and the interview technique was used as the data collection tool. The study group of the research consists of 12 graduates who have completed 
their master's degrees in the field of Educational Administration in Ankara. The maximum variation and criterion sampling method, which is one of the purposeful sampling methods, was used in the study. Variables such as gender, age, and occupation were taken as a source of diversity in the determination of the people to be selected for the study group, thus ensuring the diversity of the study group. The criterion determined in the research is that individuals have completed their master's thesis periods. Eight of the participants forming the study group of the research were female, and four were male; their ages range from 28 to 39 . Eight of the participants are teachers, two are principals, and two are civil servants. A semi-structured interview form developed by the researcher was used as the data collection tool in the research. The interview form consists of two parts. The first part is the demographic information section, which includes the age and occupation of the participants. The second part consists of the following questions; (i) What are your reasons for graduate education?, (ii) What did the thesis writing process provide you? (iii) What are the difficulties you faced during the thesis writing process?, (iv) How would you describe your feelings during the thesis process?, (v) What are your suggestions to students for this process? The interviews were conducted face-to-face with graduates who have completed the thesis process in the field of educational administration. The interviews lasted between 20 and 45 minutes. Content analysis was used in the analysis of the data.

The majority of the participants who completed their master's degree in educational administration stated that the reason for doing postgraduate education is professional and personal development. Some of them said that they had postgraduate education in order to be in such an environment and to advance in their career by interacting with the academic environment.

The majority of the participants who have completed their master's degree in Educational Management have mentioned that the thesis process has benefits for them academically, individually, and in terms of getting into a new environment. The majority of the participants emphasized that they had the opportunity to read the literature effectively, which gave them the habit of reading scientific publications.

The majority of the participants agree that the biggest challenge of the thesis process is to provide work-life balance. In the thesis process, both working in an institution and having different roles in family life can force people into the triangle of work, thesis writing, and family. As a matter of fact, the participants stated that they had problems in getting permission from the institution they work and the inadequacy of the spouses and children at home to support this process, adapting to the thesis and allocating time to work.

Regarding the feelings felt during the thesis process, it is very striking that the participants expressed their feelings as negative and complex rather than positive feelings. Participants stated that they felt anxious, hopeless, melancholic, helpless, insufficiently tired, and nervous due to reasons such 
as not being able to make it on time, worrying about failing in the jury, continuing the process just because one had to finish it, not being able to start writing, and being scattered among the topics after starting. Participants who experienced mixed feelings expressed their feelings such as the support of their counselors when they lost motivation, the thought of being successful and completing the process, climbing a long and steep staircase, but believing that there was success and victory in the end.

It is an important finding that the participants mostly emphasize the thesis topic in their proposals to those who are in the thesis process or will experience this process. As a matter of fact, since the participants associated the most important difficulty of the thesis process with the subject, they also emphasized the thesis subject in their suggestions. It has been stated that there may be difficulties in reaching the original sources of very popular topics from time to time, so they should not be studied just because they are popular. In addition, the importance of getting technical support, the importance of establishing an effective communication network with the supervisor, the importance of planning and creating a working schedule were mentioned at the point where the thesis was inadequate in the formal writing of the thesis. From this point of view, it can be stated that the suggestions of people who have experienced and completed the thesis process should be considered important, and it can be a road map for those who will start the process.

\section{Araştırmacıların Katkı Oranı Beyanı}

$\mathrm{Bu}$ araştırmanın planlanması, yürütülmesi ve yazılı hale getirilmesinde sadece tek bir araştırmacı yer almıştır.

\section{Destek ve Teşekkür Beyanı}

$\mathrm{Bu}$ araştırmada herhangi bir kurum, kuruluş ya da kişiden destek alınmamıştır.

\section{Çatışma Beyanı}

Araştırmacının araştırma ile ilgili diğer kişi ve kurumlarla herhangi bir kişisel ve finansal çıkar çatışması yoktur.

\section{Etik Kurul Beyanı}

$\mathrm{Bu}$ araştırma, Hacettepe Üniversitesi Senatosu Etik Komisyonunun 28.07.2020 tarih ve 35853172-600 sayılı onayı ile yürütülmüştür. 